\title{
SURATLANT: a 1993-2017 surface sampling in the central part of the North Atlantic subpolar gyre
}

\author{
Gilles Reverdin ${ }^{1}$, Nicolas Metzl ${ }^{1}$, Solveig Olafsdottir ${ }^{2}$, Virginie Racapé ${ }^{3}$, Taro Takahashi ${ }^{4}$, \\ Marion Benetti ${ }^{5}$, Hedinn Valdimarsson ${ }^{2}$, Alice Benoit-Cattin ${ }^{2}$, Magnus Danielsen ${ }^{2}$, Jonathan Fin ${ }^{1}$, \\ Aicha Naamar ${ }^{1}$, Denis Pierrot ${ }^{6}$, Kevin Sullivan ${ }^{6}$, Francis Bringas ${ }^{6}$, and Gustavo Goni ${ }^{6}$ \\ ${ }^{1}$ Sorbonne Université/CNRS/IRD/MNHN, Laboratoire d'océanographie et du climat: expérimentations et \\ approches numériques (LOCEAN), Paris, France \\ ${ }^{2}$ Marine and Freshwater Research Institute, Reykjavik, Iceland \\ ${ }^{3}$ Laboratoire d'Océanographie Physique et Spatiale (LOPS), CNRS/Ifremer/IRD/UBO-IUEM, Brest, France \\ ${ }^{4}$ Lamont-Doherty Earth Observatory (LDEO), Columbia University, Palisades, NY, USA \\ ${ }^{5}$ Institute of Earth Sciences, University of Iceland, Reykjavik, Iceland \\ ${ }^{6}$ National Oceanic and Atmospheric Administration/Atlantic Oceanographic Meteorological Laboratory, \\ Miami, Florida, USA
}

Correspondence: Gilles Reverdin (gilles.reverdin@locean-ipsl.upmc.fr)

Received: 9 April 2018 - Discussion started: 24 April 2018

Revised: 20 August 2018 - Accepted: 18 September 2018 - Published: 18 October 2018

Abstract. This paper presents the SURATLANT data set (SURveillance ATLANTique). It consists of individual data of temperature, salinity, parameters of the carbonate system, nutrients, and water stable isotopes $\left(\delta^{18} \mathrm{O}\right.$ and $\left.\delta \mathrm{D}\right)$ collected mostly from ships of opportunity since 1993 along transects between Iceland and Newfoundland (https://doi.org/10.17882/54517). We discuss how the data are validated and qualified, their accuracy, and the overall characteristics of the data set. The data are used to reconstruct seasonal cycles and interannual anomalies, in particular of sea surface salinity (SSS); inorganic nutrients; dissolved inorganic carbon (DIC); and its isotopic composition $\delta^{13} \mathrm{C}_{\mathrm{DIC}}$, total alkalinity $\left(\mathrm{A}_{\mathrm{t}}\right)$, and water isotope concentrations. Derived parameters such as $f \mathrm{CO}_{2}$ and $\mathrm{pH}$ are also estimated. The relation between salinity and $\mathrm{A}_{\mathrm{t}}$ is estimated from these data to investigate the possibility to replace missing $A_{t}$ when estimating other parameters of the carbonate system. When examining the average seasonal cycle in the deep ocean, in both these data with other climatologies, we find a period of small seasonal change between January and late April. On the Newfoundland shelf and continental slope, changes related with spring stratification and blooms occur earlier. The data were collected in a period of multi-decennial variability associated with the Atlantic multi-decadal variability with warming between 1994 and 2004-2007, and with the recent cooling having peaked in 2014-2016. We also observe strong salinification in 2004-2009 and fresher waters in 1994-1995 as well as since 2010 south of $54^{\circ} \mathrm{N}$ and in 2016-2017 north of $54^{\circ} \mathrm{N}$. Indication of multi-decadal variability is also suggested by other variables, such as phosphate or DIC, but cannot be well resolved seasonally with the discrete sampling and in the presence of interannual variability. As a whole, over the 24 years, the ocean $f \mathrm{CO}_{2}$ trend $\left(+1.9 \mu \mathrm{atm} \mathrm{yr}{ }^{-1}\right)$ is close to the atmospheric trend and associated with an increase in DIC $\left(+0.77 \mu \mathrm{mol} \mathrm{kg}^{-1} \mathrm{yr}^{-1}\right)$. The data also revealed a canonical $\mathrm{pH}$ decrease of $-0.0021 \mathrm{yr}^{-1}$. There is also a decrease in $\delta^{13} \mathrm{C}_{\mathrm{DIC}}$ between 2005 and 2017 (in winter, $-0.014 \% \mathrm{o} \mathrm{r^{-1 }}$, but larger in summer, $-0.042 \% \mathrm{yr}^{-1}$ ), suggesting a significant anthropogenic carbon signal at play together with other processes (mixing, biological activity). 
Copyright statement. Denis Pierrot's, Kevin Sullivan's, Francis Bringas', and Gustavo Goni's copyrights for this publication are transferred to the National Oceanic and Atmospheric Administration (NOAA).

\section{Introduction}

The North Atlantic subpolar gyre (NASPG) is a major site for formation of intermediate and deep waters and thus plays a key role in the ocean meridional overturning circulation. The upper ocean circulation brings to its southern and eastern parts relatively warm and salty water of subtropical origin. This water is then cooled by significant heat loss to the atmosphere and freshened by local excess precipitation and by inputs of fresher water from the Arctic, as well as from continental and ice cap origin (Boyer et al., 2007). Part of this upper water then flows into the Nordic Seas, whereas the other part recirculates cyclonically in the gyre, steered by topography, such as around the Reykjanes Ridge (Fig. 1). This water is progressively transformed by winter mixing into intermediate waters in the Labrador and Irminger Sea or further entrained in the dense outflows of the Nordic Seas to form Atlantic deep waters (Mercier et al., 2015; Daniault et al., 2016; Rossby et al., 2017).

This region is the only large part of the world ocean which has experienced a surface cooling trend over the last century (Rahmstorf et al., 2015). The cooling has been related to changes in the meridional overturning circulation and to an observed overall surface freshening (Friedman et al., 2017). It also experiences very large decadal to multidecadal variability (Yashayaev and Loder, 2016; Reverdin, 2010; Frajka-Williams et al., 2017; Robson et al., 2016) associated with Atlantic multi-decadal variability. This might result from atmospheric variability, as well as from changes in the strength of the meridional overturning circulation (Häkkinen and Rhines, 2004; Häkkinen et al., 2011; Hátún et al., 2005; Reverdin, 2010; Chafik et al., 2016). The most recent trend has been a large cooling and freshening since 2005, which reversed a previous warming and freshening since the mid-1990s (Robson et al., 2016). It was associated in 20142015 with particularly strong positive North Atlantic Oscillation (NAO) atmospheric conditions inducing large vertical mixing and deep convection in the Labrador Sea and the Irminger Sea (Yashayaev and Loder, 2016; Piron et al., 2017; de Jong and de Steur, 2016; Fröb et al., 2016).

The North Atlantic contributes substantially to the global oceanic uptake of $\mathrm{CO}_{2}$. This is mainly due to extensive biological activity during summer and considerable heat loss during winter, as well as due to the export of surface waters to the deep ocean by the ocean circulation and vertical mixing. As a result, a large anthropogenic carbon inventory is evaluated in this region (e.g., Khatiwala et al., 2013; Zunino et al., 2014). Takahashi et al. (2009) estimate that the annual mean air-sea $\mathrm{CO}_{2}$ flux in the North Atlantic, north of $50^{\circ} \mathrm{N}$ (representing only $5 \%$ of the ocean surface), is
$0.27 \mathrm{Pg} \mathrm{yr}^{-1}$, i.e., almost $20 \%$ of the global flux. Although the mean annual carbon flux is a robust result for the North Atlantic (Takahashi et al., 2002, 2009; Watson et al., 2009; Schuster et al., 2013) there is still disagreement in the magnitude of seasonal, interannual to decadal variability depending on the method used to evaluate air-sea $\mathrm{CO}_{2}$ fluxes (Schuster et al., 2013). Compared to other basins, the air-sea $\mathrm{CO}_{2}$ fluxes' interannual variability in the North Atlantic appears relatively small (Rödenbeck et al., 2015; Landschützer et al., 2016). However, during some periods, significant variability has been recognized at a regional scale in the North Atlantic subpolar gyre (NASPG). It is related to changes in ocean $f \mathrm{CO}_{2}$ relative to atmospheric concentrations induced by either warming or deep convection (Corbière et al., 2007; Metzl et al., 2010; Rödenbeck et al., 2014). The variations of winds also impact air-sea $\mathrm{CO}_{2}$ fluxes (Wanninkhof and Trinanes, 2017). Based on a synthesis of $p \mathrm{CO}_{2}$ observations for years 1972-2006, Takahashi et al. (2009) evaluate a mean rate of $1.8 \mu \mathrm{utm} \mathrm{yr}^{-1}( \pm 0.4)$ in the North Atlantic, i.e., close to atmospheric increase. This result was revisited and confirmed by McKinley et al. (2011) for the period 1981-2009. An analysis of recent data (2005-2014) across the NASPG near $59-60^{\circ} \mathrm{N}$ also suggests surface $f \mathrm{CO}_{2}$ trends that are near the atmospheric increase (Fröb et al., 2018). Interestingly, this study also illustrates a spatial variety of the mechanisms for these trends. For example, a large contribution of alkalinity changes related to a salinity decrease was found only in the Iceland Basin in surveys by VOS Nuka Arctica (Friederike Fröb and Are Olsen, personal communication, 2018).

The uptake of $\mathrm{CO}_{2}$ through air-sea gas exchange affects the seawater $\mathrm{CO}_{2}$ chemistry and leads to ocean acidification (Gattuso and Hansson, 2011). Over the past two decades, $\mathrm{pH}$ in North Atlantic surface waters has declined at a similar rate to global ocean $\mathrm{pH}\left(-0.0018 \mathrm{yr}^{-1}\right)$ (Lauvset et al., 2015; García-Ibáñez et al., 2016). However, in a similar way as for $f \mathrm{CO}_{2}$, the $\mathrm{pH}$ interannual variability could be significant at a regional scale. As an extreme case, based on the shorter 2001-2008 SURATLANT (SURveillance ATLANTique) winter data, Metzl et al. (2010) reported a $\mathrm{pH}$ rate of $-0.0069 \mathrm{yr}^{-1}$ associated with a particularly fast rise of oceanic $f \mathrm{CO}_{2}$ (up to $7.2 \mu \mathrm{atm} \mathrm{yr}^{-1}$ ).

Finally, the large uptake of anthropogenic $\mathrm{CO}_{2}$ in the ocean leads to a strong change in the isotopic composition of dissolved inorganic carbon (DIC), thus reducing its ${ }^{13} \mathrm{C} /{ }^{12} \mathrm{C}$ ratio (noted $\delta^{13} \mathrm{C}_{\text {DIC }}$ hereafter). The $\delta^{13} \mathrm{C}_{\text {DIC }}$ decrease in response to the human-induced perturbation is less than $-0.007 \% \mathrm{yr}^{-1}$ in polar surface regions (McNeil et al., 2001; Olsen et al., 2006), whereas it reaches $-0.025 \%$ o $\mathrm{yr}^{-1}$ in subtropical regions (Gruber et al., 1999). These observations have been used to validate oceanic models for these regions (Tagliabue and Bopp, 2008; Sonnerup and Quay, 2012). This decrease is generally masked by the seasonal cycle due to physical and biological mechanisms, which is as large as $1 \%$ in the NASPG (Gruber et al., 1999; Racapé et 


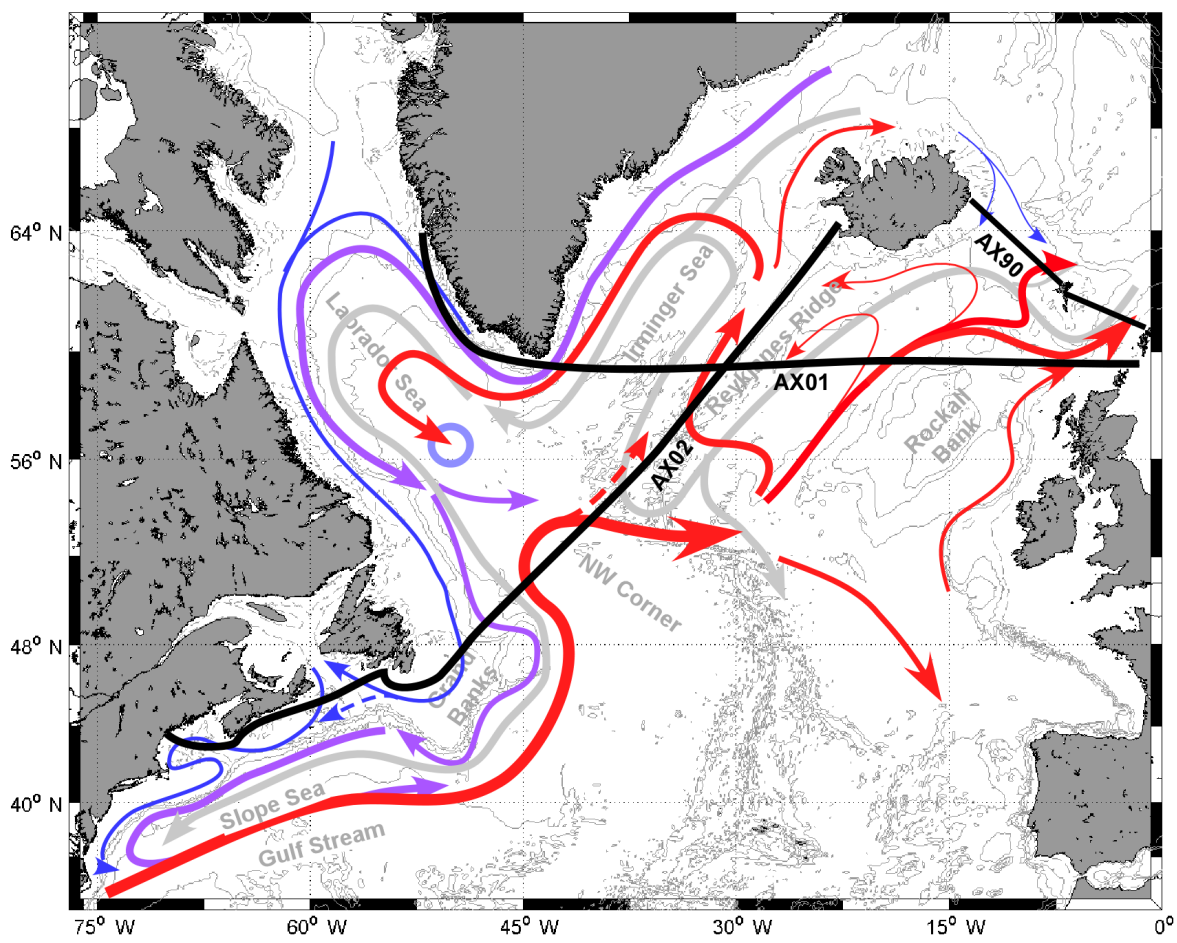

Figure 1. Monitoring of the surface subpolar gyre. SURATLANT is along ship track AX02. The red currents indicate a schematic view of surface circulation in the subpolar gyre originating from the Gulf Stream and North Atlantic Current. The blue lines indicate the path of the freshest waters of polar or continental origin, and the purple and grey arrows illustrate the deep export circulation.

al., 2014). Although $\delta^{13} \mathrm{C}_{\mathrm{DIC}}$ provides additional information allowing us to further understand mechanisms of ocean region $\mathrm{CO}_{2}$ uptake in key regions such as NASPG, its interannual to decadal variability is still poorly documented.

In order to unravel the surface NASPG variability, it is necessary to revisit the region studied by Corbière et al. (2007), Metzl et al. (2010), and Racapé et al. (2014) with a more comprehensive data set. The data set encompasses temperature $(T)$, salinity $(S)$, water stable isotopes $\left(\delta^{18} \mathrm{O}\right.$ and $\left.\delta \mathrm{D}\right)$, dissolved inorganic carbon, total alkalinity $\left(\mathrm{A}_{t}\right)$, nutrients, and $\delta^{13} \mathrm{C}_{\mathrm{DIC}}$. The 24 years of physical and geochemical data presented here cover the recent multi-decadal sea saw of warming-cooling. Hence, they might also provide an alternate view on the decadal variability in $f \mathrm{CO}_{2}$ and $\mathrm{pH}$ in the central part of the NASPG. $f \mathrm{CO}_{2}$ and $\mathrm{pH}$ are thus also computed from these data.

The data have been binned in time and in latitude bands for later use. The data and the binning method are first presented (Sect. 2). To illustrate the properties of the data set, we will then present the average seasonal cycle (Sect. 3). Finally, we will present first-order estimates of trends over the whole period (Sect. 4).

\section{Data and methods}

\subsection{Data}

Data were collected since 1993 along different container vessels operated or leased by EIMSKIP, mostly between Reykjavik (Iceland) and Argentia (southern Newfoundland). The ships most commonly crossed the NASPG in nearly 5 days - first close to the Reykjanes Ridge or to its west, reaching the Newfoundland slope southwest of $49^{\circ} \mathrm{N}, 49^{\circ} \mathrm{W}$ (AX02 transect on Fig. 1). However, weather (late autumn to early spring) and ice conditions (January-April) often influence the ship's route, so that it can also cross the central Irminger Sea or intersect meanders of the North Atlantic Current (NAC), further to the southeast. The sampling used here is largely based on surface samples collected every 3 months by a volunteer instructed at LOCEAN (or at LDEO before 1995). In addition, the ships have been equipped a large part of the time to measure continuously $T$ and $S$. First, between April 1994 and May 2007, the thermosalinograph (TSG) was a SBE21 thermosalinograph, and then between February 2011 and March 2016 it was a SBE45 micro TSG with an external temperature sensor SBE38. There was also a $f \mathrm{CO}_{2}$ equilibration system by NOAA/AOML (Rick Wanninkhof, Denis Pierrot) in 2003-2007 and 2013-2016 (data are in the SOCAT database, Bakker et al., 2016, and at http://www. aoml.noaa.gov/ocd/ocdweb/occ.html, last access: 30 January 
2018). Both the TSG and $f \mathrm{CO}_{2}$ equilibration system were installed on a water circuit pumping water at depths of 4$6 \mathrm{~m}$. Expendable bathythermograph (XBT) probes have also regularly been deployed along the AX02 transect (Fig. 1) (profiles from approximately 1200 temperature probes collected between November 2008 and April 2016 at approximately $25 \mathrm{~km}$ resolution during these transects are available on the NOAA/AOML site http://www.aoml.noaa.gov/phod/ hdenxbt/index.php, last access: 14 November 2017).

The surface samples were usually collected from an intake corresponding to water pumped between 4 and $6 \mathrm{~m}$ depending on the vessel (except in June 1993 and January 1994, when water was collected with a bucket). Initially in 1993, the water collection included samples for $S$, DIC, $\delta^{18} \mathrm{O}$ of seawater, and inorganic phosphate. These were analyzed at LDEO, but due to Gilles Reverdin moving to France the sample analysis was progressively discontinued (inorganic phosphate in late $1994, \delta^{18} \mathrm{O}$ of seawater in late 1995 , and DIC in February 1997). Analysis was then moved to other centers. Salinity sampling was never discontinued and $S$ has been analyzed since 2000 in Reykjavik (Marine and Freshwater Research Institute, MFRI). DIC and $A_{t}$ have been analyzed at LODYC/LOCEAN in Paris since June 2001. Inorganic nutrients (nitrate + nitrite, phosphate, silicic acid; later reported as $\mathrm{NO}_{3}, \mathrm{PO}_{4}, \mathrm{Si}$ ) are analyzed since December 2001 in Reykjavik (MFRI). Water stable isotopes of seawater $\left(\delta^{18} \mathrm{O}\right.$ and $\delta \mathrm{D}$ ) have been analyzed since late 2011 mostly at LOCEAN in Paris (some of these data are presented in Benetti et al., 2016, but with emphasis on the subset on the Newfoundland shelf and slope). Finally, $\delta^{13} \mathrm{C}_{\mathrm{DIC}}$ has been analyzed in 2005-2006 at the University of Washington and since 2010 at LOCEAN (Racapé et al., 2014). The $\delta^{13} C_{\text {DIC }}$ data are expressed in \%o relative to the reference V-PDB (Vienna PeeDee Belemnite) (Craig, 1957). Conversion was done for nutrients from measurements in $\mu \mathrm{mol} \mathrm{L}{ }^{-1}$ into $\mu \mathrm{mol} \mathrm{kg} \mathrm{kg}^{-1}$ assuming measurements conducted at $25^{\circ} \mathrm{C}$. The water stable isotopes $\left(\delta^{18} \mathrm{O}\right.$ and $\left.\delta \mathrm{D}\right)$ are reported as concentration in $\%$ in VSMOW (Vienna Standard Mean Ocean Water) scale (Benetti et al., 2017). Salinity is expressed as a practical salinity without unit.

Details on data collection, validation, and accuracy for all reported parameters are provided in Appendix A. An earlier version of part of the DIC / $A_{t}$ and nutrient data (1993-2013) had been made available through the PANGEA database (Reverdin et al., 2007, 2015), whereas most of the water isotope data have been contributed to the GISS database (Schmidt et al., 1999).

The seawater $\mathrm{CO}_{2}$ chemistry can be fully described with the measured DIC and $\mathrm{A}_{\mathrm{t}}$, using the dissociation constants of Lueker et al. (2000) as implemented in CO2SYS (Lewis and Wallace, 1998; Pierrot et al., 2006). $f \mathrm{CO}_{2}$ or $\mathrm{pH}$ can thus be estimated from these equations, which also requires $T$ and $S$ data (also provided; see Appendix A), as well as nutrients. When nutrient data are missing, we used in these equations the nutrient climatology derived from all the data at the cal- endar date of the sampling. The error in doing this has little impact on the computation for this region. When no $A_{t}$ was measured with DIC such as before 2001 and for some samples in 2005 and 2006, it is also possible to use parameterized $A_{t}$ based on salinity. The strong correlation between sea surface alkalinity and salinity in the open ocean can be described with an empirical linear relationship (Millero et al., 1998; Friis et al., 2003). In our previous analysis we used a relation based on seasonal SURATLANT data but only for years 2001-2002 (Corbière et al., 2007; Metzl et al., 2010).

$\mathrm{A}_{\mathrm{t}}=45.808 \times S+713.5$

$\left(r^{2}=0.92\right.$, RMSD $\left.= \pm 10.3 \mu \mathrm{mol} \mathrm{kg}{ }^{-1}\right)$

Here, an updated formula is derived for $S>34$ based on all the reported SURATLANT data in 2001-2016.

$\mathrm{A}_{\mathrm{t}}=45.5337 \times S+713.58$

$\left(r^{2}=0.83, \mathrm{RMSD}= \pm 8.3 \mu \mathrm{mol} \mathrm{kg}{ }^{-1}\right)$

This relation is close to the one derived by Nondal et al. (2009) for the North Atlantic:

$\mathrm{A}_{\mathrm{t}}=49.35 \times S+582$.

Our formula has a larger 0-crossing and explains a large part of the variance in $\mathrm{A}_{t}$, at least for $S$ larger than 34 (Fig. 2). For the lower salinities found on the Newfoundland shelf, different sources of freshwater (from the Arctic or resulting from continental or sea ice melt inputs) contribute to deviations from the relation. The impact on $f \mathrm{CO}_{2}$ or $\mathrm{pH}$ of using this relationship instead of others or measured $\mathrm{A}_{t}$ is discussed in Appendix B.

Trends in estimated seawater $f \mathrm{CO}_{2}$ will be compared to other reported trends and to trends in atmospheric fugacity. Atmospheric $\mathrm{CO}_{2}$ mean mole fraction data were provided by the Cooperative Global Atmospheric Data Integration Project (Dlugokencky et al., 2017). Here, the $x \mathrm{CO}_{2}$ data collected at Mace Head, Ireland $\left(53.3^{\circ} \mathrm{N}\right)$, were used, after some editing (mostly removing situations with a breeze from the land). The $x \mathrm{CO}_{2}$ data were converted to fugacities at $100 \%$ humidity following Weiss and Price (1980). The $x \mathrm{CO}_{2}$ trend at Mace Head is $1.9 \mathrm{ppm} \mathrm{yr}^{-1}$ in 1993-2016, increasing to $2.1 \mathrm{ppm} \mathrm{yr}^{-1}$ in 2006-2016, which is coherent with global average trends (e.g., Le Quéré et al., 2018). Local values of atmospheric $f \mathrm{CO}_{2}$ present significant spatial differences at subpolar latitudes depending on wind regimes, but they do not have much influence on the long-term atmospheric trends.

\subsection{Methods}

\subsubsection{Binning the time series}

$T$ and $S$ anomaly time series (Reverdin et al., 2018a) are presented as Hovmöller diagrams in Appendix C. The sample data used here reproduce a good part of this long-term 
(a) At $\left[\mu \mathrm{mol} \mathrm{kg}^{-1}\right]$ at depth $[\mathrm{m}]=0$

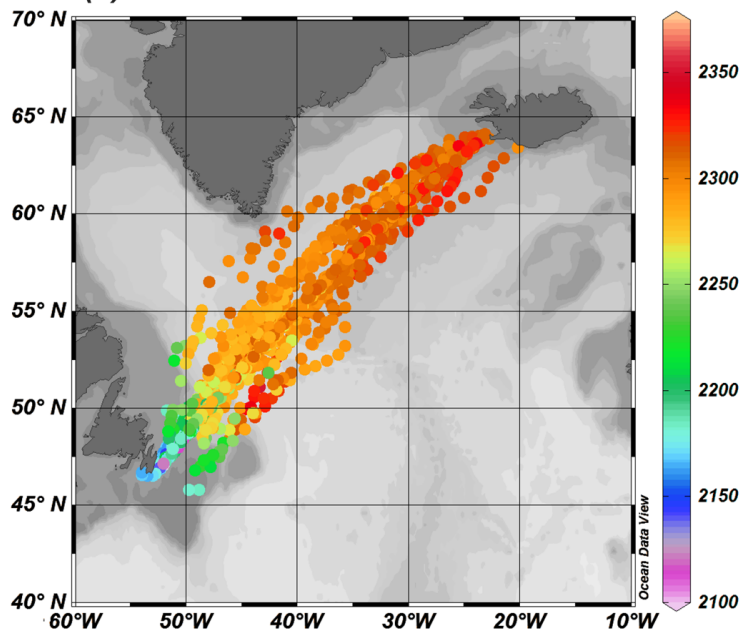

(b)

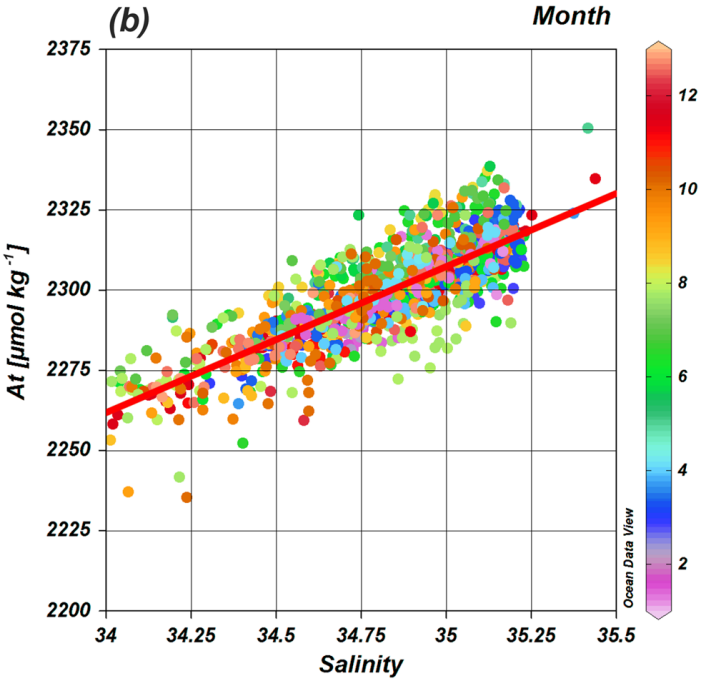

Figure 2. (a) Spatial distribution of the $A_{t}$ samples collected in 2001-2016 and used to estimate a regression to salinity (for $S>34$ ) (color corresponds to the $\mathrm{A}_{\mathrm{t}}$ value). (b) $\mathrm{A}_{\mathrm{t}}-S$ dispersion diagram. The red line corresponds to the $\mathrm{A}_{\mathrm{t}}=45.5337 \times S+713.58$ best fit (with rms $=8.3 \mu \mathrm{mol} \mathrm{kg}^{-1}, R^{2}=0.83$, and $n=1280$ for $S>34$ ).

variability. However, sampling is insufficient to properly separate the interannual variability from longer-term changes. The discrete sampling also results in uncertainties in estimating a seasonal cycle, in particular for parameters such as $\delta^{13} \mathrm{C}_{\mathrm{DIC}}$ or $\delta^{18} \mathrm{O}$ which have been sampled for a longer period.

We estimate an average seasonal cycle in 2001-2017. To reduce uncertainties in estimating an average seasonal cycle, we first remove from individual data an expected dependency in $S$ estimated by linear regression for $\mathrm{A}_{\mathrm{t}}$, DIC, $\delta^{18} \mathrm{O}$, and $\delta \mathrm{D}$ (as done in Friis et al., 2013). For $\mathrm{A}_{t}$, this is the $\mathrm{A}_{t}-S$ regression mentioned above, as well as for water stable isotopes, as done in Benetti et al. (2016). For nutrients, we normalize by $S / 35$. We then also remove an average trend for DIC over 1993-2017 and for $\delta^{13} C_{\text {DIC }}$ over 2005-2017 (see Sect. 4). Then, we bin the data in five $4^{\circ}$ boxes from $46-50$ to $62-64^{\circ} \mathrm{N}$ (see boxes on Fig. 3). The southern box covers the shelf and slope area and incorporates only samples for which $S<34.1$. The next box from $50-54^{\circ} \mathrm{N}$ incorporates only samples with $S$ between 34 and 35 to avoid including shelf water or from the North Atlantic Current. A shift in $S$ variability is observed in the data close to $54^{\circ} \mathrm{N}$ (see Appendix C), which separates box 2 from box 3. We also remove data collected too far west in the western Irminger Sea or central Labrador Sea as well as too far east in the western Iceland Basin (altogether data from six transects). Then, in each box, data are binned by month and year. For a given month and box, the means for individual years are averaged. The seasonal cycle obtained is then further filtered with a $1 / 4,1 / 2$, and $1 / 4$ running average over successive months, as some of the calendar months were sampled over very few years (worse for the southern shelf box in January-
May). Standard deviations of samples from this smoothed seasonal cycle are largest during the periods with largest variability. Typically this happens in spring time (May-June) for parameters influenced by phytoplankton blooms. We present the average seasonal cycle, renormalized (except for $T$ and $S$ ), so that it corresponds to $S=35$, and for DIC and $\delta^{13} \mathrm{C}$ with the trend added to correspond to 2010. Uncertainty resulting from the sampling was not plotted. This uncertainty is difficult to estimate properly (as it is due both to interannual variability and variability within the same transect). It is, however, usually much smaller than the seasonal cycle amplitude portrayed.

\subsubsection{Estimating trends}

Trends are estimated separately from the seasonal cycle, although the two are intertwined due to the irregular time sampling. Earlier papers (Corbière et al., 2007; Metzl et al., 2010) mostly considered trends in winter. Here, trends are based either on all data or on data collected in one season (without removing the seasonal average, and without the normalization discussed in Sect. 2.2.1). Furthermore, either the whole domain is considered or only data between 50 and $63^{\circ} \mathrm{N}$, which present less scatter, thus resulting in more robust trend estimates. Alternatively, the deviations from the average seasonal cycle are estimated in each box, but we will not discuss them further here. This is done for DIC, $\mathrm{A}_{t}$, $f \mathrm{CO}_{2}, \mathrm{pH}$, and $\delta^{13} \mathrm{C}_{\mathrm{DIC}}$ and for different periods. Only the most characteristic trend estimates are presented, in order to compare them with results of other products and analyses. 


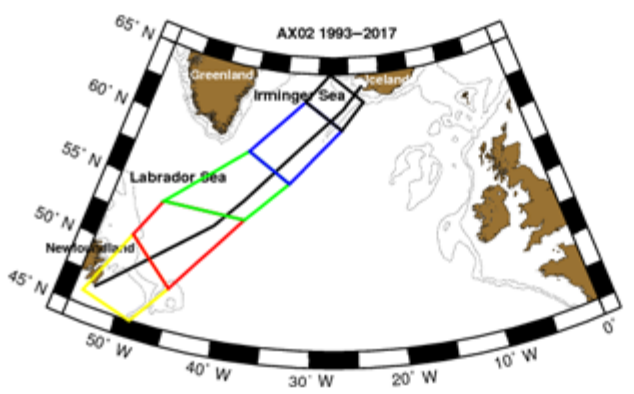

Average seasonal cycle
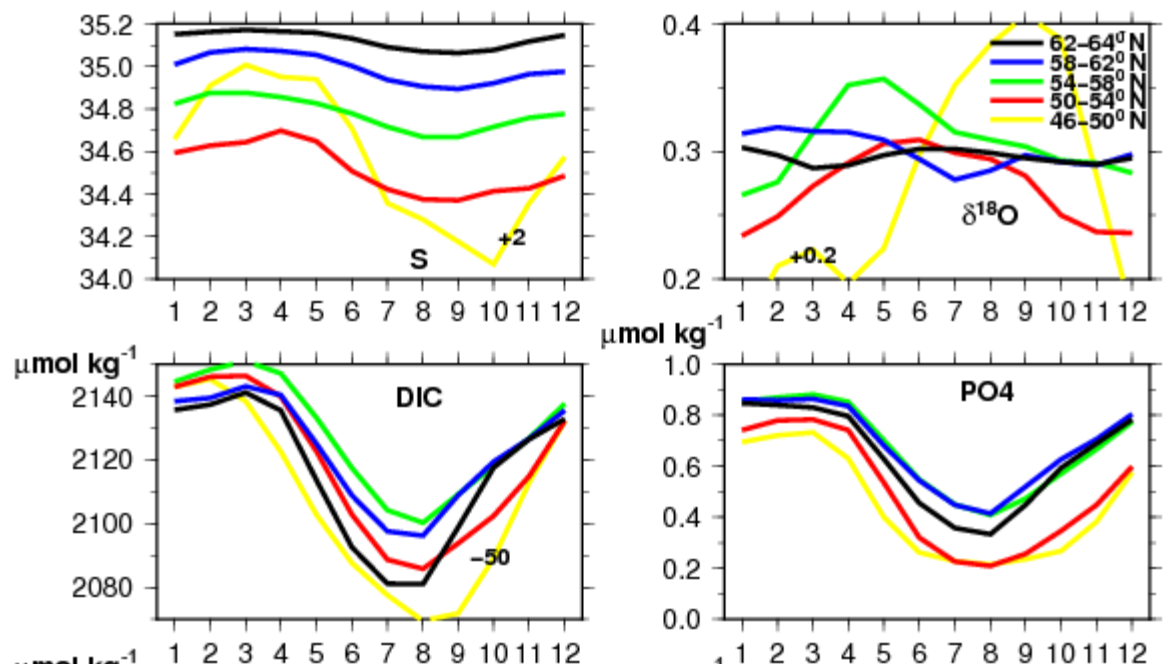

$\mu \mathrm{mol} \mathrm{kg-1}$

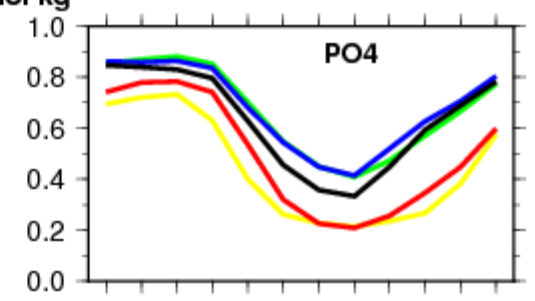

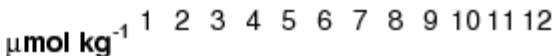
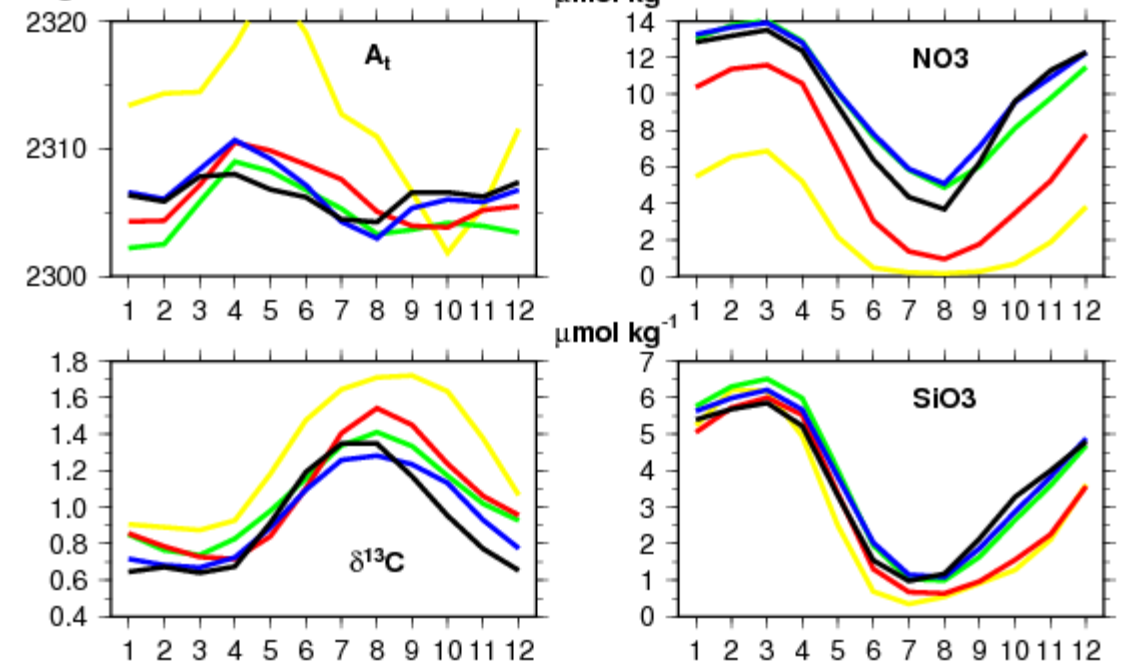

$\begin{array}{lllllllllll}\mathrm{m}^{-1} 1 & 2 & 3 & 4 & 5 & 6 & 7 & 8 & 9 & 101112\end{array}$

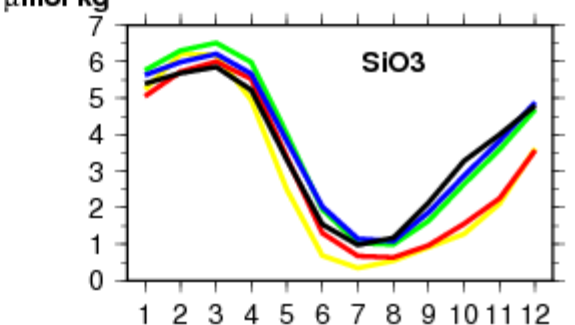

Figure 3. Average seasonal cycle in 2001-2017. For DIC, $\mathrm{A}_{t}, \delta^{18} \mathrm{O}, \mathrm{PO}_{4}, \mathrm{NO}_{3}$, and $\mathrm{Si}$, it is normalized for $S$ variations and reported at $S=35$. The color of the curves corresponds to geographical boxes presented in the upper-right corner (yellow, red, green, blue, and black from south to north; the black trajectory correspond to January 2017 sampling). Yellow curves (south) for $S$, $\delta^{18} \mathrm{O}$, and DIC have been shifted. $S$ is a practical salinity with no unit; $\delta^{18} \mathrm{O}$ and $\delta^{13} \mathrm{C}_{\text {DIC }}$ are expressed in \%o (per mil). A map with the location of the boxes is also provided. 


\section{Seasonal cycle}

In this section, we will present the average seasonal cycle portrayed in the 2001-2017 data (Fig. 3). For $T$ (not presented), one finds a seasonal cycle range increasing from north $\left(4^{\circ} \mathrm{C}\right)$ to south $\left(12.3^{\circ} \mathrm{C}\right.$ in yellow box over the shelves and $6.4^{\circ} \mathrm{C}$ offshore in red box; corresponding boxes are on the top panel of Fig. 3). This is close to the ranges portrayed in SST (sea surface temperature) climatologies, such as HadSST3 (Kennedy et al., 2011). The seasonal cycle in $S$ (Fig. 3) is also found as described at the surface in the World Ocean Database 2013 (WOD13; Boyer et al., 2013) with a maximum in February-May (February-April on shelf) followed by a gradual decline until a minimum in September $\left(\right.$ October, north of $\left.62^{\circ} \mathrm{N}\right)$. The amplitude also increases from north to south.

For the other parameters, the seasonal cycle presented has been normalized as described in Sect. 2.2.1 and reported for $S=35$.

The DIC seasonal cycle presents (Fig. 3) a maximum in March and a minimum in July (north) transitioning to August (south). The amplitude is at a maximum on the Newfoundland shelf $\left(73 \mu \mathrm{mol} \mathrm{kg}{ }^{-1}\right)$ and north of $62^{\circ} \mathrm{N}(70 \mu \mathrm{mol} \mathrm{kg}-1)$, and it is smallest for $58-62^{\circ} \mathrm{N}\left(48 \mu \mathrm{mol} \mathrm{kg}{ }^{-1}\right)$. There is a slight decrease from March to April, indicating the beginning of carbon consumption during blooms, and a very steep decline in April to May.

$A_{t}$ (Fig. 3) has much smaller seasonal variability than DIC (here expressed as deviation from average relationship $\mathrm{A}_{\mathrm{t}}-$ $S$ ), with estimated uncertainties of several $\mu \mathrm{mol} \mathrm{kg}{ }^{-1}$, which is not small compared with the seasonal cycle amplitude (uncertainties are larger on the shelf in January-May). After a minimum in February, there is a peak in April in the interior and later (May-June) north of $62^{\circ} \mathrm{N}$ and on the Newfoundland shelf, followed by a decrease until August north of $54^{\circ} \mathrm{N}$ (and later further south). The $A_{t}$ increase could be associated with late winter or early spring blooms reducing $\mathrm{NO}_{3}$ and $\mathrm{PO}_{4}$ for the formation of organic matter and decreasing DIC. The latter $A_{t}$ decrease could be associated with calcifying organisms such as coccolithophores, which are known to produce large late spring or early summer blooms in this part of the Atlantic, usually well past the large diatomdominated blooms (Signorini et al., 2012)

The $\delta^{13} \mathrm{C}_{\text {DIC }}$ seasonal cycle (Fig. 3) updates Racapé et al. (2014). It mirrors the cycle in DIC, with a maximum $\delta^{13} \mathrm{C}_{\text {DIC }}$ in July in the north shifting to August further south (and even early September on the shelf). This increase of $0.7 \%$ or more compared to late winter is associated with production of organic matter and the associated fractionation. The decrease later in the year is associated with remineralization and vertical mixing with depleted subsurface water (Racapé et al., 2013). Notice also a small spatial gradient in winter with increasing values from north to south (and decreasing salinity).
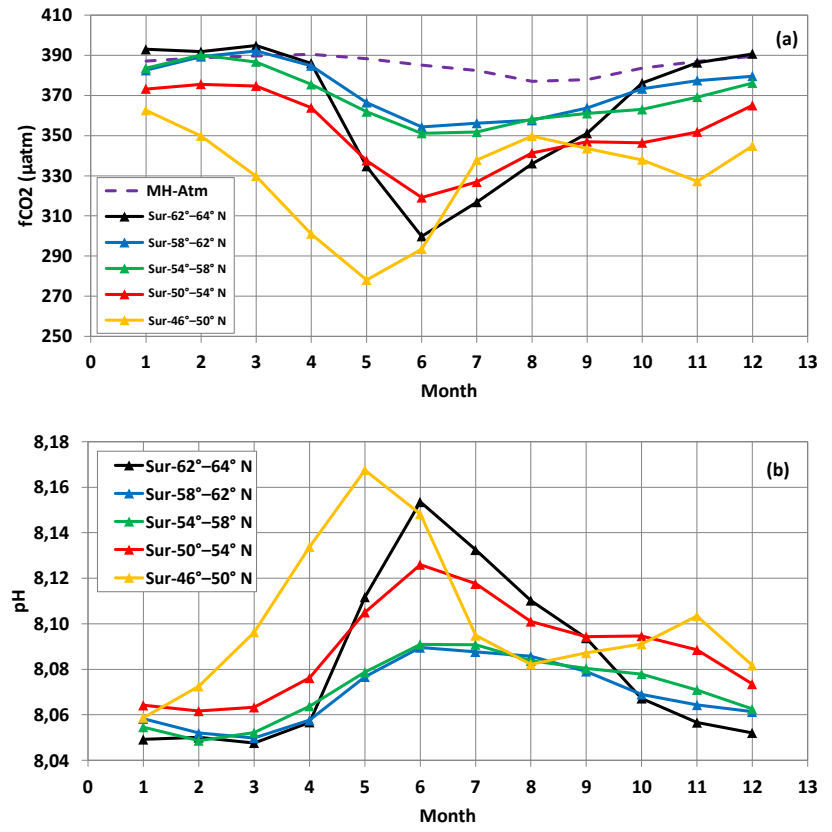

Figure 4. Seasonal cycles of $f \mathrm{CO}_{2}$ (a) and $\mathrm{pH}$ (b) in each box. On (a) the purple dashed line is the mean monthly atmospheric $f \mathrm{CO}_{2}$ derived from $\mathrm{CO}_{2}$ concentrations at Mace Head station for year 2010 .

The three nutrients present a March maximum (as for DIC) associated with maximum entrainment of subsurface water in the mixed layer. Then, they present a slight decrease until April and a larger decrease until a July minimum for $\mathrm{Si}$ and an August minimum for $\mathrm{PO}_{4}$ and $\mathrm{NO}_{3}$. This shift in the time of the minima between the three nutrients suggests a dominance of non-siliceous organisms in the later portion of the bloom, when $\mathrm{Si}$ levels have been strongly depressed. For $\mathrm{PO}_{4}$ and $\mathrm{NO}_{3}$ there is a north to south decrease in the nutrients (but not so much for $\mathrm{Si}$ ) in all seasons. The southward decrease is even stronger for $\mathrm{NO}_{3}$ on the Newfoundland shelf, a sign of the contribution of fresher water from the Pacific Ocean and western Arctic having experienced denitrification on the shelves (McTigue et al., 2016). In particular, summer $\mathrm{NO}_{3}$ levels are very low south of $54^{\circ} \mathrm{N}$. The seasonal cycle of the three nutrients is consistent with climatologies available from WOD13 and also with the time series station in the Irminger Sea close to Iceland (Olafsson et al., 2010).

$\delta^{18} \mathrm{O}$ and $\delta \mathrm{D}$ (not shown) present no significant seasonal deviations from their average relationship with $S$ north of $58^{\circ} \mathrm{N}$. At $54-58^{\circ} \mathrm{N}$, there is an early winter minimum and a maximum in April-May, during a period with overall small salinity seasonal variability. South of $50^{\circ} \mathrm{N}$, in the shelf region, one finds a late summer maximum as described near the shelf break in Benetti et al. (2016), where it was related to sea ice meltwater. The $50-54^{\circ} \mathrm{N}$ latitude range presents an intermediate situation between the seasonal cycles in these two regions with a spring to September maximum. 

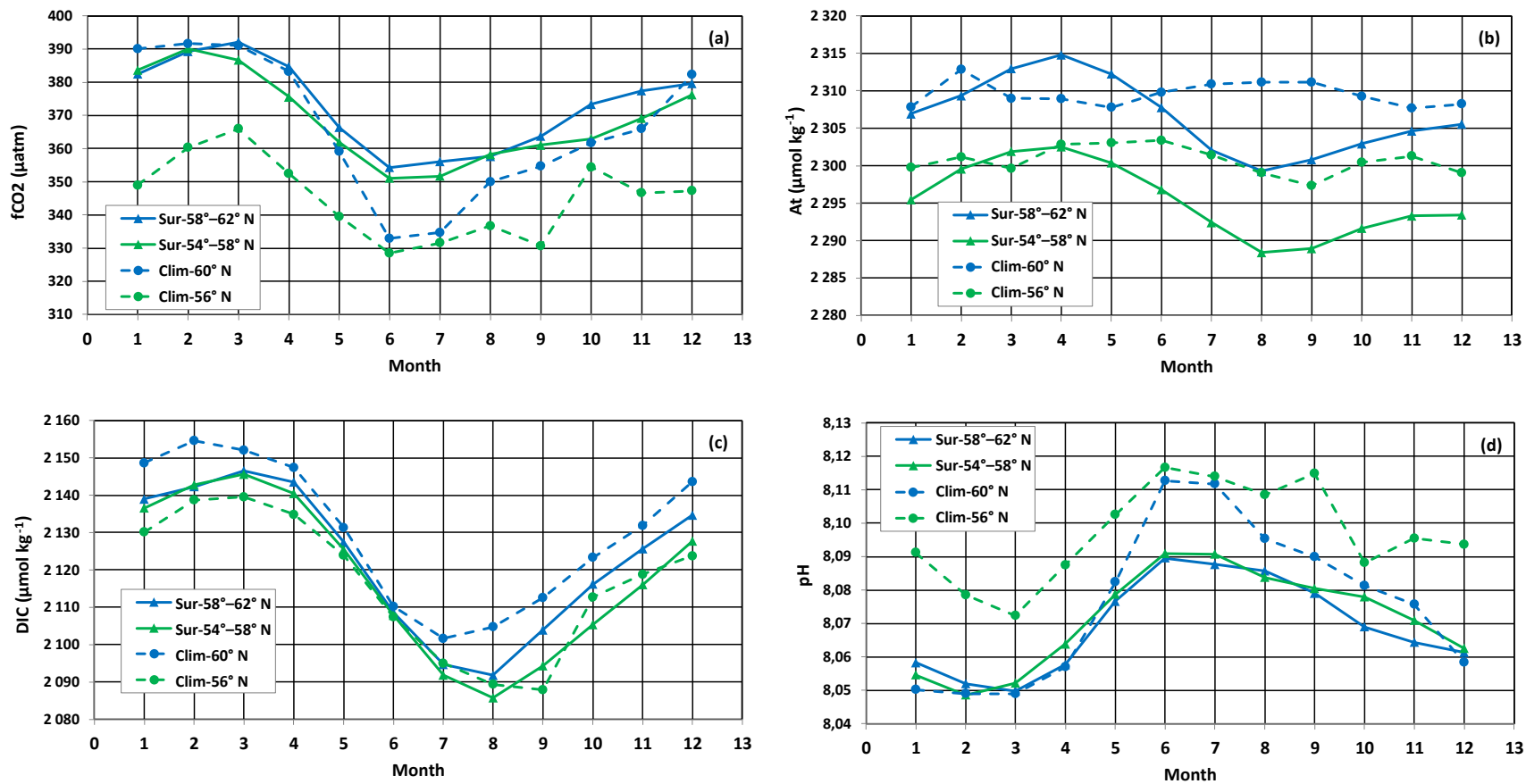

Figure 5. Seasonal cycles of $f \mathrm{CO}_{2}(\mathbf{a}), \mathrm{A}_{\mathrm{t}}(\mathbf{b})$, DIC (c), and $\mathrm{pH}(\mathbf{d})$ derived from SURATLANT data and the climatology (Takahashi et al., 2014) for the central region (boxes $54-58$ and $58-62^{\circ} \mathrm{N}$ ).

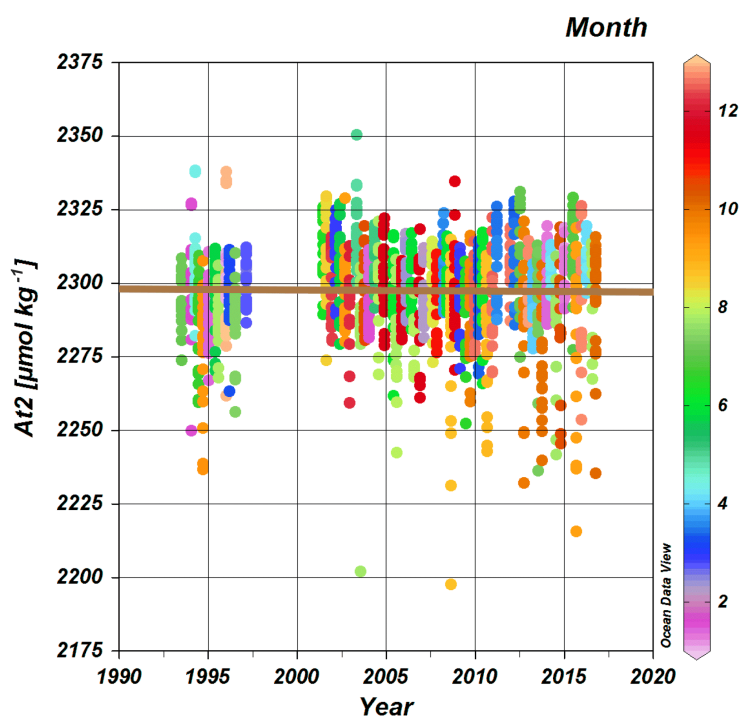

Figure 6. Time series of $A_{t}$ observed in the latitudinal band 50$63^{\circ} \mathrm{N}$. For 1993-1997 A $\mathrm{t}$ was derived from salinity. The brown line depicts the long-term trend $\left(-0.036( \pm 0.058) \mu \mathrm{mol} \mathrm{kg}{ }^{-1} \mathrm{yr}^{-1}\right)$; i.e., no trend was detected for $A_{t}$. Low $A_{t}$ values $\left(<2250 \mu \mathrm{mol} \mathrm{kg}^{-1}\right)$ were observed near $50^{\circ} \mathrm{N}$. The color corresponds to calendar month (right scale).
Finally, the $f \mathrm{CO}_{2}$ and $\mathrm{pH}$ seasonal cycles are estimated from monthly mean DIC and $A_{t}$, as well as SST, SSS (sea surface salinity), and nutrients (Fig. 4) Here, we do it without normalizing to $S=35$, in order to compare $f \mathrm{CO}_{2}, \mathrm{pH}$, and DIC seasonal cycles with the climatology constructed by Takahashi et al. (2014). Except for the southern region (46$\left.50^{\circ} \mathrm{N}\right), f \mathrm{CO}_{2}$ presents a pronounced maximum in FebruaryMarch associated with vertical mixing and entrainment of remineralized DIC in the surface layer. It presents a minimum in June associated with the carbon use during the spring bloom. Similarly to DIC described above, the $f \mathrm{CO}_{2}$ seasonality is most pronounced in the most northern box (amplitude $90 \mu \mathrm{atm})$ and in the most southern box ( $80 \mu \mathrm{atm}$ from January to May). In both regions, the $f \mathrm{CO}_{2}$ seasonal cycle exhibits a secondary maximum (August) and minimum (November), as in the climatology. In the central regions $\left(54-58\right.$ and $58-62^{\circ} \mathrm{N}$ ) the seasonal $f \mathrm{CO}_{2}$ amplitude is on the order of $40 \mu \mathrm{atm}$. The $f \mathrm{CO}_{2}$ values in these two boxes are very close for each month, as was also found for DIC and nutrients (Fig. 3). The oceanic $f \mathrm{CO}_{2}$ values are close to (in December-March in the north) or well below the atmospheric level (Fig. 4a). The largest ocean $\mathrm{CO}_{2}$ sink is observed in the southern region in May $\left(f \mathrm{CO}_{2}^{\text {ocean }}-f \mathrm{CO}_{2}^{\text {atm }}=\right.$ $-110 \mu \mathrm{atm})$ as found in the climatology (Takahashi et al., $2009,2014)$ and regularly observed in recent years (5 May cruises in 2004-2015, Wanninkhof and Pierrot, in Bakker et al., 2016). The $\mathrm{pH}$ seasonal cycle (Fig. 4b) mostly mirrors (with reverse sign) the seasonal cycle in $f \mathrm{CO}_{2}$ (Fig. 4a), 

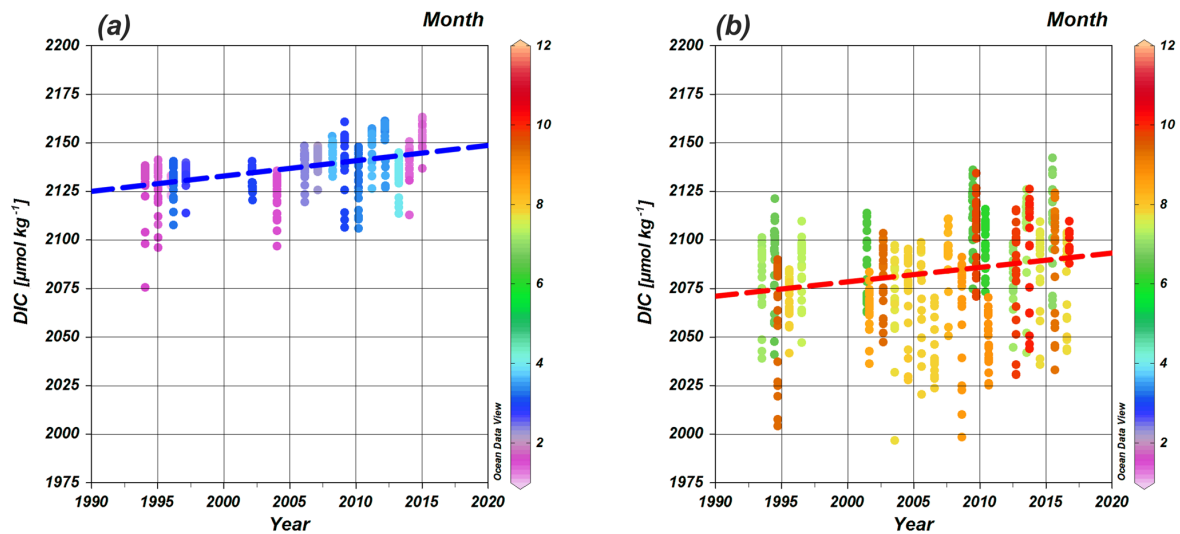

Figure 7. Time series of DIC observed in the latitudinal band $50-63^{\circ} \mathrm{N}$ for winter (January-March, a) and summer (June-September, b). The dashed lines depict the long-term trend $\left(+0.787( \pm 0.081) \mu \mathrm{mol} \mathrm{kg}^{-1} \mathrm{yr}^{-1}\right.$ in winter, $+0.765( \pm 0.133) \mu \mathrm{mol} \mathrm{kg}^{-1} \mathrm{yr}^{-1}$ in summer $)$. The color corresponds to calendar month (right scale).
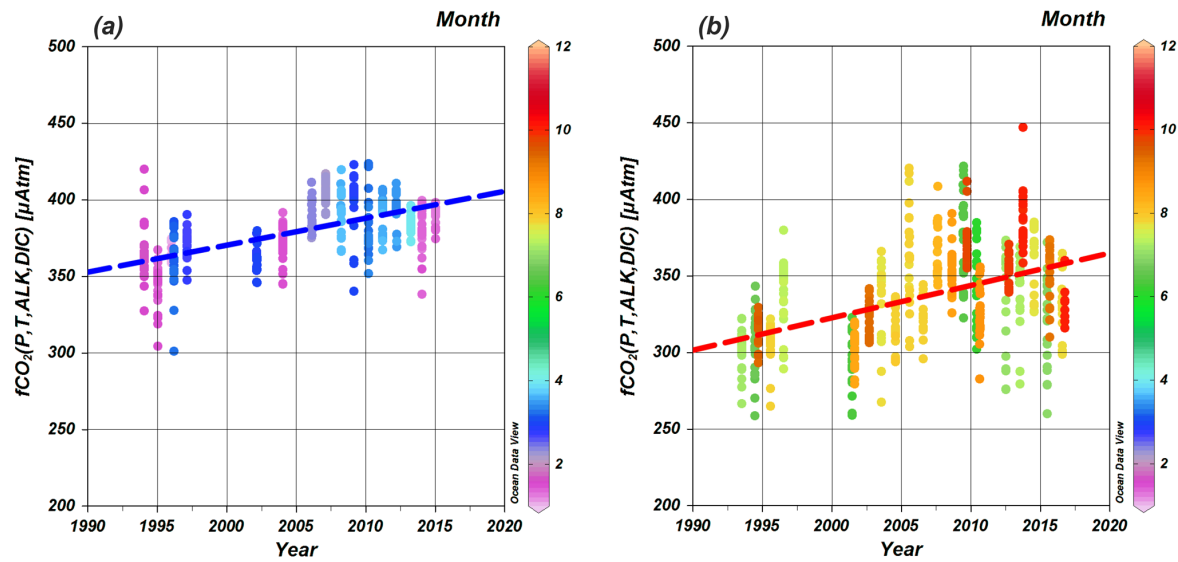

Figure 8. Time series of $f \mathrm{CO}_{2}$ in the latitudinal band $50-63^{\circ} \mathrm{N}$ for winter (January-March, a) and summer (June-September, b). The dashed lines depict the long-term trend $\left(+1.757( \pm 0.123) \mu \mathrm{atm} \mathrm{yr}^{-1}\right.$ in winter and $+2.060( \pm 0.155) \mu \mathrm{utm} \mathrm{yr}^{-1}$ in summer $)$. The color corresponds to calendar month (right scale).

and its amplitude ranges between 0.04 (in the gyre) and more than 0.1 (in the south and north).

For $f \mathrm{CO}_{2}, \mathrm{~A}_{\mathrm{t}}$, DIC and $\mathrm{pH}$ seasonal cycles, we present (Fig. 5) comparisons to the climatological seasonal cycle (Takahashi et al., 2014) for the two boxes in the central gyre (54-58 and $\left.58-62^{\circ} \mathrm{N}\right)$ where we observed homogeneous properties (Fig. 3). There are a few methodological differences between the two products. The climatology (Takahashi et al., 2014) is reported for reference year 2005, whereas the SURATLANT seasonal cycle constructed with 2001-2017 data is referenced to year 2010 (Sect. 2.2.1). The climatology for DIC and $\mathrm{pH}$ was calculated from $f \mathrm{CO}_{2}$ observations and reconstructed alkalinity, whereas for SURATLANT, it is $f \mathrm{CO}_{2}$ and $\mathrm{pH}$ that are computed from observed DIC and $\mathrm{A}_{\mathrm{t}}$. At $56^{\circ} \mathrm{N}$ (green lines), the $f \mathrm{CO}_{2}(\mathrm{pH})$ climatology is low (high) compared to SURATLANT, but with rather similar seasonality. At $60^{\circ} \mathrm{N}$ (blue lines), $f \mathrm{CO}_{2}$ and $\mathrm{pH}$ seasonal- ity are stronger in the climatology with a more pronounced $f \mathrm{CO}_{2}$ minimum and $\mathrm{pH}$ maximum in June-July, and results are similar in other seasons (August-May). For both regions, the $A_{t}$ seasonal amplitude is most pronounced in the SURATLANT data (about $10-15 \mu \mathrm{mol} \mathrm{kg}{ }^{-1}$, Fig. 5b), with the largest difference in August. Despite these differences, the DIC cycles derived from independent observations and methods are very similar (Fig. 5c), which is typical of all regions.

\section{Trends}

We show the trends over the full period (1993-2016), using all data or restricted to the latitude range $50-63^{\circ} \mathrm{N}$, and separately in summer (June-September) or winter (JanuaryMarch). In this latitude range, $A_{t}$ does not show any trend (Fig. 6), as well as salinity or nutrients (not shown). 

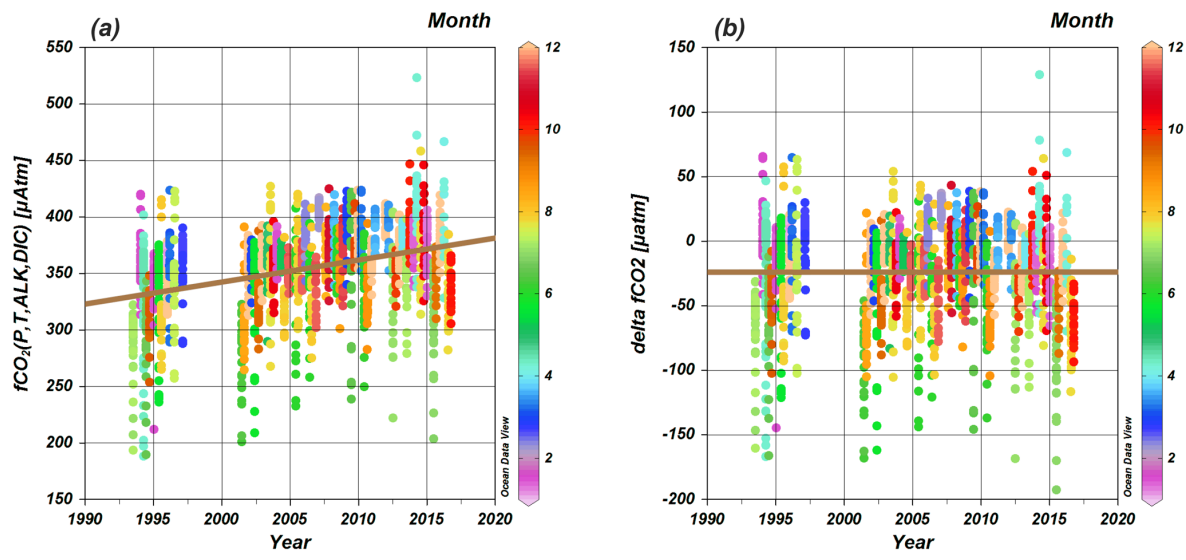

Figure 9. Time series of $f \mathrm{CO}_{2}$ (a) and $\delta-f \mathrm{CO}_{2}$ (b) for all SURATLANT data. The brown lines depict the long-term trends

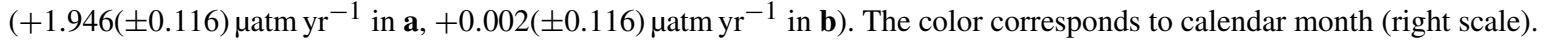

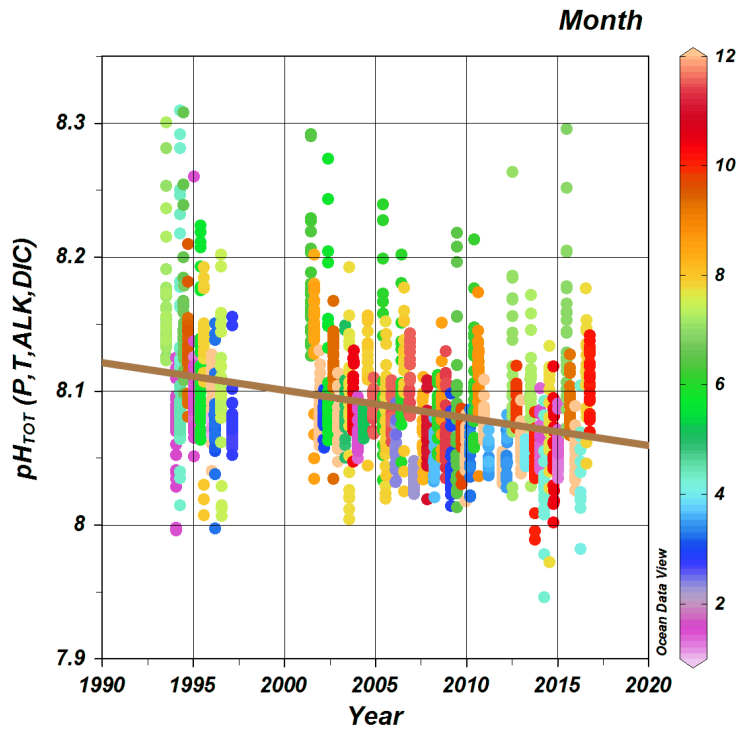

Figure 10. Time series of $\mathrm{pH}$ SURATLANT data. The brown line depicts the long-term trend $\left(-0.00206( \pm 0.0001) \mathrm{yr}^{-1}\right)$. Note high $\mathrm{pH}$ (> 8.2) observed in coastal regions (north or south). The color corresponds to calendar month (right scale).

In contrast, we find positive trends for DIC $(\sim+0.79$, $0.76 \mu \mathrm{mol} \mathrm{kg} \mathrm{gr}^{-1}$ ) respectively for winter and summer (notice no winter data included in 2016 or 2017) (Fig. 7). This trend is about half the one reported by Olafsson et al. (2009), based on winter observations in the northern Iceland Sea for years $1985-2008\left(+1.4 \mu \mathrm{mol} \mathrm{kg}^{-1} \mathrm{yr}^{-1}\right)$, but close to the trend observed over 1990-2015 in the Irminger Sea upper ocean waters $\left(+0.63 \mu \mathrm{mol} \mathrm{kg}^{-1} \mathrm{yr}^{-1}\right)$, a signal mainly explained by anthropogenic carbon uptake (Fröb et al., 2018). As also suggested by $\delta^{13} \mathrm{C}_{\text {DIC }}$ data (described below), the positive DIC trend derived from SURATLANT data (Fig. 7) is likely due to anthropogenic $\mathrm{CO}_{2}$. Also, interest- ingly, in both seasons, the SURATLANT data present almost no trend until 2005, which corresponds to SST (and AMO) maximum. This lack of a DIC trend in the early part of the record was also reported in Metzl et al. (2010). This first part of the record also corresponds usually to a period of decreasing winter winds (decrease in frequency of the $\mathrm{NAO}+$ situation) and thus an expected decrease in winter mixed layer depths (and also a decrease in subpolar gyre circulation).

For $f \mathrm{CO}_{2}$ positive trends are found as expected (Fig. 8). In the band $50-63^{\circ} \mathrm{N}$, the summer $\left(+2.1 \mu \mathrm{atm} \mathrm{yr}^{-1}\right)$ and winter $\left(+1.76 \mu \mathrm{atm} \mathrm{yr}^{-1}\right)$ trends are close to the atmospheric increase. This is in the range of the long-term trend (2530 years) estimated in the North Atlantic by Takahashi et al. (2009) and McKinley et al. (2011), but much lower than values near or above $+3 \mu \mathrm{utm}^{-1}$ previously reported for years 1993-2006 (Corbière et al., 2007; Schuster et al., 2009) or 2001-2008 (Metzl et al., 2010). This is also much larger than the $+1.1 \mu \mathrm{atm} \mathrm{yr}^{-1}$ trend estimated by Lauvset et al. (2015) for years 1991-2011 in the NASPG. This highlights that the $f \mathrm{CO}_{2}$ trend is quite sensitive to the period (and data) selected (Fay and McKinley, 2013). Also, when using all data (all seasons and regions) the $\mathrm{fCO}_{2}$ trend is $+1.9 \mu \mathrm{atm} \mathrm{yr}^{-1}$ (Fig. 9a) so that the $\delta-f \mathrm{CO}_{2}$ (difference between ocean and atmospheric fugacities) presents no significant trend (Fig. 9b), suggesting that in this region the air-sea $\mathrm{CO}_{2}$ fluxes driven by $\delta-f \mathrm{CO}_{2}$ (and winds) would also have presented a small trend. Although temperature interannual variations (up to $+1.5^{\circ} \mathrm{C}$ in 2005 , or $-1.5^{\circ} \mathrm{C}$ in 2015 ; see Fig. B1) could explain rapid $f \mathrm{CO}_{2}$ changes for some periods (Corbière et al., 2007), over the longer term the $f \mathrm{CO}_{2}$ trends presented here are mainly explained by DIC (with $A_{t}$ being relatively constant). The same is true for $\mathrm{pH}$ (Fig. 10) and its negative trend of $-0.0021 \mathrm{yr}^{-1}$ mirrors the $f \mathrm{CO}_{2}$ trend. Similarly to the $f \mathrm{CO}_{2}$ trend, this $\mathrm{pH}$ trend for the NASPG is close to the mean global ocean estimate of $-0.0018 \mathrm{yr}^{-1}$ (Lauvset et al., 2015). It is also comparable to other trends evaluated in the North Atlantic polar waters, ranging between 

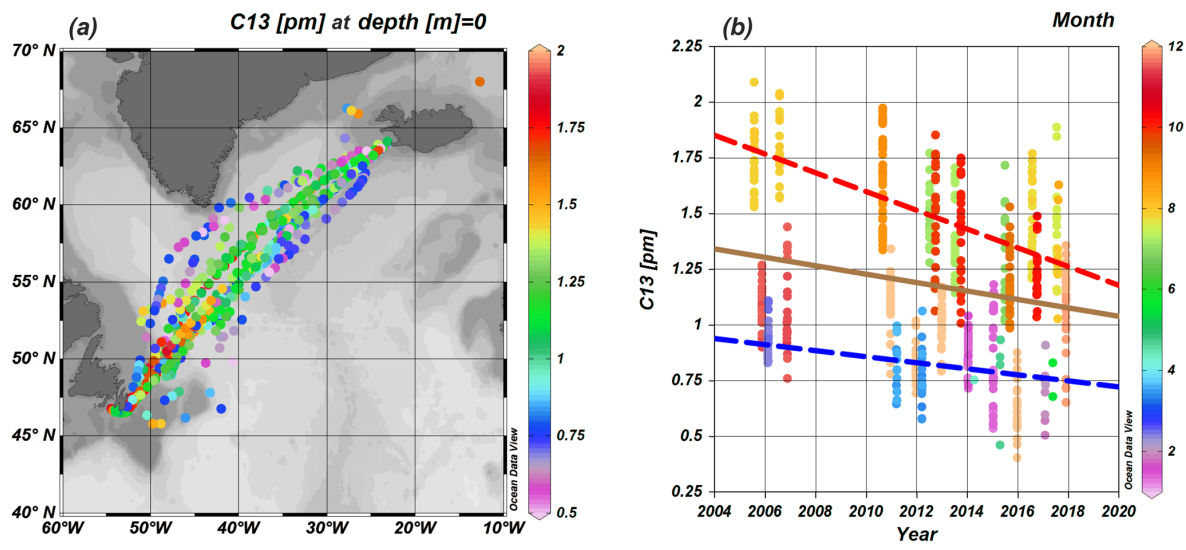

Figure 11. Trend for $\delta^{13} \mathrm{C}_{\mathrm{DIC}}$. (a) Data distribution (2005-2017); (b) time series with the trend for the summer season (red dashed line: trend $\left.-0.0420( \pm 0.0032) \mathrm{yr}^{-1}\right)$, trend for winter season (blue dashed line, trend $\left.-0.0136( \pm 0.0031) \mathrm{yr}^{-1}\right)$, and all seasons (brown dashed line, trend $\left.-0.0189( \pm 0.0036) \mathrm{yr}^{-1}\right)$ (notice that data have been adjusted by +0.05 in $2005-2006$ and by +0.13 since 2010$)$. The color in (a) corresponds to the $\delta^{13} \mathrm{C}_{\mathrm{DIC}}$ value and in (b) corresponds to the calendar month (right scale).

-0.0017 and $-0.0026 \mathrm{yr}^{-1}$ depending on the periods, seasons, and regions (Bates et al., 2014; Lauvset and Gruber, 2014; Lauvset et al., 2015; Olafsson et al., 2009). Compared to the Irminger Sea, the difference of $\mathrm{pH}$ trends is mainly explained by observed DIC trends $\left(+0.8 \mu \mathrm{mol} \mathrm{kg}^{-1} \mathrm{yr}^{-1}\right.$ for NASPG against $+1.6 \mu \mathrm{mol} \mathrm{kg}{ }^{-1} \mathrm{yr}^{-1}$ for Irminger Sea, Bates et al., 2014).

For $\delta^{13} \mathrm{C}_{\text {DIC }}$, we find significant trends in all seasons for the 2005-2017 period for which samples are available. The winter trend $\left(-0.014 \% \circ \mathrm{yr}^{-1}\right)$ is smaller than the summer trend $\left(-0.042 \% \mathrm{orr}^{-1}\right)$ (Fig. 11). Both are small compared to the seasonal cycle and have large uncertainties, due to the small number of years sampled. Notice also that the summer season presents large seasonal changes (Fig. 3). Furthermore, the trend estimates strongly depend on the adjustments that we apply separately to the data before and after 2010 (see Appendix A3). The trends have a similar magnitude before and after 2010, although the summer trend is sensitive to the large positive deviations of August 2010 data (see Racapé et al., 2014), with lower trends in 2010-2017 when not including it $\left(-0.0040\right.$ vs. $\left.-0.042 \% \mathrm{yr}^{-1}\right)$. Altogether, the surface winter trend deduced from the adjusted data set is lower than the expected Suess effect in the atmosphere $\left(-0.025 \% \mathrm{orr}^{-1}\right.$, based on current change rates in atmospheric $\delta^{13} \mathrm{CO}_{2}$, such as from the Alert station, White et al., 2015). It is also comparable with model estimates in the NASPG for other periods from Sonnerup and Quay $\left(2012 ;-0.12 \%\right.$ decade $^{-1}$ over the period 1970-1995) and from Tagliabue and Bopp (2008; $-0.10 \%$ odecade ${ }^{-1}$ between 1970 and 2005).

\section{Data availability}

The data set is freely available and is accessible at http://www.seanoe.org/data/00434/54517/ (https://doi.org/10.17882/54517, Reverdin et al., 2018b).

\section{Conclusions}

The SURATLANT data set in 1993-2017 is mostly based on a discrete collection of surface samples (currently 2832 data points during 76 transects, but not always for all parameters). The collection methods and the parameters analyzed have not always been the same, due to funding as well as logistical and analytical issues. We have documented data issues and have thus edited the data set. The accuracy of the data is usually well documented (see Appendix A). We could not address whether there are remaining issues due for example to contamination of the water samples from pipes or water collection on-board a ship, or due to storage in bottles before analysis in a laboratory. We also derive a new $\mathrm{A}_{t}-S$ relationship adapted to the data set that can be used to estimate $f \mathrm{CO}_{2}$ and $\mathrm{pH}$, as well as other parameters of the carbonate systems, for example when $A_{t}$ was not measured in 1993-1997.

The sampling is found to be sufficient to document the average seasonal cycle of most parameters analyzed in this region. Thus, it provides a coherent data set for process analyses and/or biogeochemical ocean model validation. It is also sufficient for documenting long-term trends (1993-2017) in different seasons. These trend estimates illustrate the characteristics of the data set and are in the bulk range of other studies. However, because of both large interannual and decadal variability (for example indication of evolution that is different in the warming period until 2005 and then afterwards), these estimates are difficult to compare with other analyses, without further observed or modeled information on the ocean variability. Furthermore, the possibility of large spatial variability in these signals could complicate the comparison. For example, VOS Nuka Arctica data (Friederike Fröb and Are Olsen, personal communication, 2018) document a large spatial change in the recent decrease in SSS across the 
Reykjanes Ridge that implies (based on $f \mathrm{CO}_{2}$ observations) different decadal trends in DIC between the two regions.

However, part of the scatter we find in the discrete sample data set results from insufficient sampling of the seasonal variability. To provide a more complete analysis, it will be important to combine this set with other data, either from the same ships of opportunity (operated mostly by NOAA/AOML) or from other platforms. These include nearcontinuous underway surface temperature and salinity from TSGs, as well as $p \mathrm{CO}_{2}$ measured with equilibrator systems. Notice also that information on mixed layer depth and stratification was often provided by near-simultaneous XBT profiles. The investigation should also include the compilations of station data in GLODAP (Global Ocean Data Analysis Project; Olsen et al., 2016) or the surface SOCAT (Bakker et al., 2016) database. There is also a large array of complementary observations, such as from the Argo and the bioArgo profiling platforms (Organelli et al., 2017). For example, these data suggest blooms in midwinter that could be associated with net production and export of nutrient and carbon from the surface layer already in March (Lacour et al., 2017). Notice, however, that the bio-Argo floats have mostly sampled the rim of the subpolar gyre and provide only indirect evidence on near-surface carbon and nutrient that they did not measure. Thus, combining the different in situ cruise data sets with the Argo data will provide other challenges. The data set presented here combined with these other data should contribute to model validation in the spirit of what was done in Thomas et al. (2008), Keller et al. (2012), Rödenbeck et al. (2014), or Schuster et al. (2013) for DIC, $A_{t}$, and $f \mathrm{CO}_{2}$ or in Tagliabue and Bopp (2008) for $\delta^{13} \mathrm{C}_{\mathrm{DIC}}$. 


\section{Appendix A: Data methods and uncertainties}

We will review the different parameters analyzed and discuss the uncertainties, as well as anomalies observed.

\section{A1 Salinity and temperature}

Most of the time salinity is obtained from water samples analyzed by a salinometer in a laboratory within 3 months of collection, and its accuracy is usually of 0.01 or better. In a few instances, the salinity reported originates from the validated and adjusted TSG salinity data archived in the SSS repository at LEGOS (www.legos.obs-mip.fr/observations/sss, last access: 14 November 2017). The adjustment of the TSG salinity data results mostly from comparison with the water samples collected from a water faucet at the TSG as well as with upper-level data of Argo floats found nearby. The TSG salinity data usually have an accuracy better than 0.03 (Alory et al., 2015).

Temperature data originate from different streams. In April 1994-April 1996, the reported $T$ was measured at an intake in close contact to the outside seawater temperature (near 4-6 m). This was also the case for reported data in July-August 2017 originating from the R/V Thalassa during the RREX2017 cruise (Thierry, 2017). At other times, the reported $T$ was measured by the TSG and adjusted to estimate a sea temperature, by correcting warming in pipes based on comparison with $5 \mathrm{~m}$ temperatures from XBTs deployed along the transects. We expect these $T$ data from the TSG repository at LEGOS to have an accuracy of $0.1^{\circ} \mathrm{C}$.

In July 1993, January 1994, and in spring and autumn 2017 $T$ was measured from a bucket rinsed and filled at the sea surface close to the aft end of the ship. These bucket measurements usually have an accuracy of $0.1^{\circ} \mathrm{C}$, except in highwind conditions, when they are less accurate. During some cruises, SST was not directly measured and was provided from expendable bathythermographs launched close in time to the collection of the water samples, with an accuracy probably better than $0.5^{\circ} \mathrm{C}$. In rarer occasions, SSM/I satellitederived microwave SSTs collocated at the ship time and position were used, and for two transects in July 2016 and October 2016, upper-level $T$ values from nearby Argo profiles were also used as a proxy. In those cases, the accuracy of $T$ reported is on the order of $1{ }^{\circ} \mathrm{C}$.

\section{A2 Inorganic macro-nutrient (nitrate, phosphate, silicic acid) concentrations}

Samples for macro-nutrient concentrations were collected starting in late 2001 in pre-cleaned $250 \mathrm{~mL}$ low-density polyethylene bottles that were frozen on-board (for two crossings, the samples were probably not correctly frozen and were discarded). For spring and summer samples, filtering was done before measuring the macro-nutrient concentrations of nitrate (including nitrite), phosphate, and silicate.
They were measured usually within 3 months of collection with standard colorimetric methods at the Marine Research Institute (Reykjavik, Iceland). The analytical procedure and the quality control for the nutrient analyses have been described in detail in Olafsson et al. (2010) where the long-term accuracy has been estimated as $\pm 0.2 \mu \mathrm{mol} \mathrm{kg}^{-1}$ for nitrate (includes also nitrite) and silicate and $\pm 0.03 \mu \mathrm{mol} \mathrm{kg}^{-1}$ for phosphate. Additional uncertainties could result from contamination during collection or from poor conservation of the nutrients in the frozen samples. In particular this can result in occasional elevated levels in phosphate, which are discarded when too far from neighboring samples with similar $T, S$, and DIC or from the expected largest values. Values of phosphate were deemed too low in January 2017, when it was found that most of the water had gone through some storage, resulting in a too-large contribution of particulate phosphate to total inorganic phosphate.

Samples for phosphate in 1993-1994 were poisoned and analyzed at LDEO (Columbia University, New York) shortly after the return of the water samples. Samples during RREX2017 (July-August 2017) were pasteurized, kept cool, and analyzed 5 months after the cruise at UMS IMAGO of IRD in Brest, France. Samples from the different laboratories have not been intercompared and are reported as such.

\section{A3 Dissolved inorganic carbon and total alkalinity}

Since June 2001, water samples collected on the ship have been shipped back to LOCEAN (Paris), where they are stored at $4{ }^{\circ} \mathrm{C}$ and analyzed within 3 months of collection. No filtration is done; thus, there might be a small amount of particulate inorganic carbon measured as well. DIC is determined at the same time as total alkalinity $\left(\mathrm{A}_{t}\right)$ by potentiometric titration derived from the method developed by Edmond (1970) using a closed cell. Calibrated Certified Reference Material (CRM) provided by Andrew Dickson (Scripps Institution of Oceanography, San Diego, USA) is regularly analyzed to standardize the hydrochloric acid and to provide an analytical uncertainty on the DIC and $A_{t}$ data. Analytical accuracy of the DIC and $A_{t}$ concentrations is $\pm 3 \mu \mathrm{mol} \mathrm{kg}{ }^{-1}$ (further details in Corbière et al., 2007). Most of the bottles used at LOCEAN since 2003 were $500 \mathrm{~mL}$ round bottles with screw caps (before that and for a few isolated samples since 2003 , the $500 \mathrm{~mL}$ bottles had a ground glass stopper and Apiezon grease was used). For some of these bottles, we found that samples presented systematic biases in 2010 2015 , either in DIC or $A_{t}$. This led to the replacement of some bottles in July 2015, and, after that, most bottles were from a newer set. Dilution by the $\mathrm{HgCl}_{2}$ solution is corrected for, assuming that it contains no DIC and does not contribute to $A_{t}$. Since December 2011, the volume of the saturated $\mathrm{HgCl}_{2}$ solution was set at $0.3 \mathrm{~mL}$. In earlier years, the solution volume varied, usually between 0.1 and $0.5 \mathrm{~mL}$, and sometimes it was not well known, which results in less certain corrections for the dilution effect. Furthermore, for the 
Table A1. Comparisons of DIC and $A_{t}$ samples shared between LOCEAN and other institutes $(1,2,3,4)$. Institute 1 uses a manometric method for measuring DIC; institutes 2, 3, and 4 use a coulometric method for DIC; and institutes 3 and 4 use a potentiometric method for $A_{t}$. The different columns are for institute number, months and year of sampling, number of samples, average, and RMS difference (LOCEAN - other) first for DIC, then for $A_{t}$.

\begin{tabular}{|c|c|c|c|c|c|c|c|}
\hline Institute & Month/year & No. of samples & Average diff. & RMS & No. of samples & Average diff. & RMS \\
\hline 1 & $01 / 2005-11 / 2006$ & 115 & -2.9 & 7.0 & & & \\
\hline 2 & $6-8 / 2010$ & 15 & -6.5 & 3.4 & & & \\
\hline 3 & $8 / 2010$ & 9 & -4.4 & 3.1 & 10 & -0.6 & 4.1 \\
\hline 4 & $8 / 2010$ & 9 & -5.0 & 4.0 & 10 & 2.3 & 4.8 \\
\hline 3 & $1 / 2015$ & 8 & -5.4 & 3.6 & 8 & 1.5 & 7.3 \\
\hline 3 & $6 / 2015^{*}$ & 15 & 4.1 & 5.9 & 15 & 13.4 & 6.5 \\
\hline 3 & $9 / 2015^{*}$ & 14 & -15.1 & 8.3 & 14 & 4.9 & 8.5 \\
\hline 2 & $4-10 / 2016$ & 9 & -0.7 & 4.6 & & & \\
\hline
\end{tabular}

* For 06/2015, bottles from LOCEAN were deemed suspicious (code added for $A_{t}$ samples); for 09/2015, values from Institute 3 were deemed suspicious.

period June 1993-February 1997, the samples were stored in bottles with a ground glass stopper with the use of Apiezon grease, and DIC was determined by a coulometric method at LDEO (Chipman et al., 1993). For some samples in 20052006 associated with a $\delta^{13} \mathrm{C}_{\text {DIC }}$ value, DIC was also estimated manometrically during the acid $\mathrm{CO}_{2}$ extraction procedure with lesser accuracy $\left( \pm 5 \mu \mathrm{mol} \mathrm{kg}{ }^{-1}\right)$. We used these DIC values when there was no DIC estimated at LOCEAN.

We first edited the data to remove suspicious values. In some instances, errors resulted from poor sample conservation in the bottles before analysis. For example, we often noticed erroneously large DIC and $\mathrm{A}_{t}$ values from specific bottles in 2010-2015. There are also a few transects when samples had to be discounted. In one case (April 2007) this happened because the samples were stored in a very hot space before shipment to France. For April 2015 (and to a lesser extent in June 2015), DIC values were too high for unknown reasons (it is possible the bottles had aged), and for January 2017, both DIC and $A_{t}$ were discounted as the origin of the water collected was suspicious (a problem also encountered for salinity samples and with the phosphate, with an anomalous contribution of particulate phosphate). In April 2015, we adjusted the DIC values by $-10.3 \mu \mathrm{mol} \mathrm{kg}-1$ based on comparisons of estimated $f \mathrm{CO}_{2}$ with those directly measured that are in the AOML and SOCAT database. When an adjustment is done, the data flag is changed from "good" to "probably good".

The LOCEAN DIC values were compared for some crossings with DIC samples collected at the same time and analyzed in other laboratories (during crossings in 2005, 2006, 2010,2015 , and 2016, which altogether involved four laboratories). These comparisons summarized in Table A1 (average and rms standard deviation) reveal for individual transects LOCEAN DIC were often lower by $5 \mu \mathrm{mol} \mathrm{kg}{ }^{-1}$ or more, but this is far from being systematic. There can also be issues of poor conservation of some of the other water samples and uncertainties in their analysis, so this is not an absolute vali- dation of the LOCEAN values. Often, the comparisons for $A_{t}$ (in 2010, 2015, and 2016, except for June 2015 and September 2015 as explained in the table) suggest small average differences. For $A_{t}$ there were other comparisons of samples collected in the same region and analyzed both at LOCEAN and ICM/CSIC during the OVIDE cruises (every 2 years between 2002 and 2016) but with a different set of LOCEAN bottles than for SURATLANT. They suggest a similarly close agreement between $A_{t}$ analyzed in the two laboratories (for example, average difference of $+0.1(\sigma=3.4$, $n=57) \mu \mathrm{mol} \mathrm{kg}^{-1}$ for the 2014 GEOVIDE cruise, Sarthou and Lherminier, 2014). A recent international intercomparison on two shared water batches (spring 2017) suggests that the LOCEAN analysis presents a small negative bias both for $\mathrm{A}_{\mathrm{t}}$ and DIC (Emily Bockmon and Andrew Dickson, personal communication 2018), but not in a very similar range of values to the ones observed during SURATLANT.

Whether these results are relevant for the whole data set needs to be further ascertained. We can nonetheless expect that the DIC and $A_{t}$ reported in the SURATLANT data set have uncertainties always smaller than $10 \mu \mathrm{mol} \mathrm{kg}^{-1}$. We can also expect that they present biases in time, but that the uncertainty is usually less than $10 \mu \mathrm{mol} \mathrm{kg}{ }^{-1}$. To provide further validation, we take advantage of the fact that, during some transects, sea surface $f \mathrm{CO}_{2}$ underway measurements were also conducted using instrumentation as described by Pierrot et al. (2009). These data are available at AOML (http: //www.aoml.noaa.gov/ocd/ocdweb/occ.html, last access: 30 January 2018) and regularly submitted and qualified in SOCAT (Bakker et al., 2016). We have selected these data within 2 min time of discrete samples and compared them with $f \mathrm{CO}_{2}$ calculated from DIC, $\mathrm{A}_{\mathrm{t}}$ pairs. For this comparison we only use samples when DIC and $A_{t}$ were measured (excluding $A_{t}$ derived from salinity when $A_{t}$ was not measured). A total of 172 points have been collocated for different years (2004-2007 and 2014-2015), for almost all seasons (months: January, February, April, June, July, and October- 

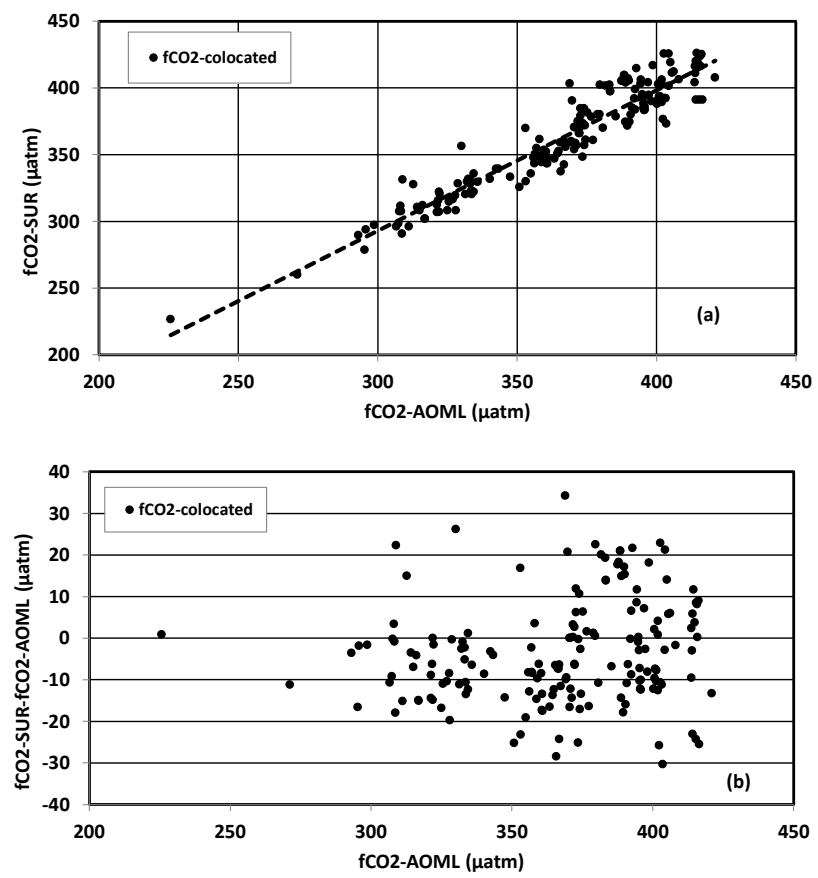

Figure A1. (a) $f \mathrm{CO}_{2}$ calculated vs. $f \mathrm{CO}_{2}$ measured ( $\mu$ atm) for 172 colocated samples. Dashed line: $f \mathrm{CO}_{2}-\mathrm{SUR}=1.05 f \mathrm{CO}_{2}-$ AOML $\left(r^{2}=0.9\right)$. (b) $f \mathrm{CO}_{2}$ differences vs. $f \mathrm{CO}_{2}$ measured for same samples ( $\mu$ atm).

December). These data represent a large $f \mathrm{CO}_{2}$ range (225$420 \mu \mathrm{atm}$, Fig. A1a). We find both positive and negative differences (Fig. A1b) that are not associated with years, seasons, SST, DIC, or $\mathrm{A}_{\mathrm{t}}$ concentrations. The mean difference ( $f \mathrm{CO}_{2}$ calc- $f \mathrm{CO}_{2}$ mes) of $-3.6( \pm 12.4) \mu$ atm is thus attributed to method uncertainties (including sampling time, measurement errors, and data processing). These new results (mean and deviation) are in the same range as those obtained in previous comparisons $(n=54$, mean difference $=$ $-2.3( \pm 11.1) \mu a t m$, Metzl et al., 2010) but for different, fewer data and a different formula used to compute $f \mathrm{CO}_{2}$. We thus conclude that $f \mathrm{CO}_{2}$ and $\mathrm{pH}$ calculated here with discrete DIC, $A_{t}$ data are suitable to interpret both seasonality and trends. This also suggests that the random error in DIC and $A_{t}$ is smaller than the worst-case scenario mentioned above of $10 \mu \mathrm{mol} \mathrm{kg}{ }^{-1}$.

A4 $\quad \delta^{13} \mathrm{C}_{\mathrm{DIC}}$

Over the period 2005-2006, acid $\mathrm{CO}_{2}$ extraction was done for $\delta^{13} \mathrm{C}_{\text {DIC }}$ measurements from helium stripping technique. This analytical method has been described previously by Quay and Stutsman (2003). These measurements have an accuracy of $\pm 0.02 \%$ for $\delta^{13} \mathrm{C}_{\text {DIC }}$ based on a helium stripping technique adapted from the one used by Kroopnick (1974) and $\pm 5 \mu \mathrm{mol} \mathrm{kg}^{-1}$ for DIC based on a comparison to coulometric DIC values and to Certified Reference Material pro- vided by Andrew Dickson (Scripps Institution of Oceanography, San Diego, USA). However, the DIC values of these samples were higher by an average $5 \mu \mathrm{mol} \mathrm{kg}{ }^{-1}$ than the LOCEAN DIC. If this was caused by a small remineralization of dissolved organic DIC, and based on the relationship described in Racapé et al. (2014), this could be associated with a negative bias of $-0.05 \%$ in $\delta^{13} \mathrm{C}_{\text {DIC }}$. Thus, we chose to correct these pre-2006 data by $0.05 \%$.

Over the period 2010-2017 during most of the SURATLANT cruises, $\delta^{13} \mathrm{C}_{\text {DIC }}$ values were measured by mass spectrometry via an acid $\mathrm{CO}_{2}$ extraction method in a vacuum system developed by Kroopnick (1974), whereas further details on the sampling methods and analytical techniques are provided in Racapé et al. (2014) for $\delta^{13} C_{\text {DIC }}$. Water was collected in small glass bottles poisoned by at least $1 \mathrm{~mL}$ of a saturated solution of mercuric chloride and stored in the dark when possible at $4{ }^{\circ} \mathrm{C}$ (at least, after return to the lab, when it was stored for up to a year before analysis). Data of some crossings were dismissed, probably because poisoning had been insufficient, and for one crossing the mass spectrometer did not function properly. Other isolated samples were dismissed either because not enough gas was collected after acidification or due to possible leaks on the mass spectrometer gas lines. These $\delta^{13} \mathrm{C}_{\mathrm{DIC}}$ values are expected to have a precision of $\pm 0.01 \%$ (Vangriesheim et al., 2009 ) and a reproducibility of $\pm 0.02 \%$. Issues on the accuracy of other $\delta^{13} \mathrm{C}_{\text {DIC }}$ samples from LOCEAN have been raised, and LOCEAN participated in an interlaboratory comparison run by Claire Normandeau (Dalhousie University) with deep NASPG water samples conditioned by Dalhousie University. The results suggest that recent LOCEAN samples have a slightly poorer reproducibility $( \pm 0.04 \%$ o ) than earlier ones. These comparisons suggest an average bias of LOCEAN measurements of $-0.13 \%$. This is less than the $0.25 \%$ o ( -0.20 to $-0.30 \%$ ) bias corrected in the GLODAP database for LOCEAN samples collected during North Atlantic cruises in 2002 and 2006 and analyzed with the same method and standards as here. This adjustment was based on the intercomparison of different cruises (Becker et al., 2016), which could nonetheless include a part due to anthropogenic signal. We chose to adjust all the LOCEAN values (samples collected in 2010-2017) by $+0.13 \%$.

\section{A5 Water isotopologs}

Since December 2011, the oxygen isotopic composition of discrete seawater samples has been usually analyzed with a Picarro CRDS (cavity ring-down spectrometer; model L2130-I isotopic $\mathrm{H}_{2} \mathrm{O}$ ) at LOCEAN-IPSL (Paris, France). The internal references, which have been used to calibrate the data in the VSMOW scale, have been previously calibrated using IAEA VSMOW reference water and vary from -6.61 to $2.24 \%$ o for $\delta^{18} \mathrm{O}$ and from -44.3 to $3.31 \%$ for $\delta \mathrm{D}$. All internal reference waters are stored in steel bottles with a slight overpressure of dry nitrogen to avoid evaporation 
processes and exchanges with ambient air humidity. Based on repeated analyses of an internal laboratory standard over several months, the accuracy of the measurements is usually better than $\pm 0.05 \%$ for $\delta^{18} \mathrm{O}$ and $\pm 0.50 \%$ for $\delta \mathrm{D}$. All seawater samples before April 2016 have been distilled to avoid salt accumulation in the vaporizer and its potential effect on the measurements (e.g., Skrzypek and Ford, 2014). Between April and July 2016, as well as since May 2017, the analysis has been often done without distillation and with a salt trap mesh. Samples in September-October 2016, January 2017, and a few samples in May and August 2017 were instead analyzed on a GV Instruments Isoprime dual-inlet isotoperatio mass spectrometer (IRMS) coupled with the Aquaprep sample preparation system (at IES, Reykjavik, Iceland). The different methods are fully described in Benetti et al. (2017). All samples in 1993-1995 were analyzed on a similar Isoprime dual-inlet IRMS system but at LDEO. Most of the samples done on IRMS were only run for $\delta^{18} \mathrm{O}$. A recent study (Benetti et al., 2017) suggests that different corrections have to be applied on the data depending on the method used to report the data in absolute concentration scale. We followed their recommendations and adjusted data to the absolute concentration scale, except for the following cases. For the $\delta^{18} \mathrm{O}$ values of samples in 1993-1995, for which the information on the internal standard used has been lost (although it probably was deep Atlantic Ocean water), we assume that they are already reported in the concentration scale and apply no correction. For the December 2011 section, samples were analyzed either by the Picarro CRDS (but without distillation) or at LOCEAN with a GV Instruments Isoprime dual-inlet IRMS coupled with the Aquaprep sample preparation system (with $\delta^{18} \mathrm{O}$ adjusted to the Picarro measurements), and the accuracy of these samples is not as high (probably closer to $\pm 0.10 \%$ for $\delta^{18} \mathrm{O}$ and $\pm 1.00 \%$ for $\delta \mathrm{D}$ ). Finally, for data of a 2017 run with a different salt trap mesh, we found a slight additional bias that was also corrected.
Appendix $B: A_{t}-S$ relationship and resulting uncertainties in estimating $f \mathrm{CO}_{2}$ and $\mathrm{pH}$

As explained in Sect. 2.1, we constructed an $A_{t}-S$ linear relationship by least-squares fitting on the SURATLANT data (2001-2016) for $S$ larger than 34, mixing all seasons. The $R^{2}$ correlation coefficient is 0.83 with rms deviations of $8.3 \mu \mathrm{mol} \mathrm{kg}{ }^{-1}$ (for $S$ larger than 34), which is larger than the uncertainty on the measurements. We also suggested when describing the seasonal cycle of $A_{t}$ in Sect. 3 that part of the scatter could be due to seasonal variability. Here, we will document what effect the choice of relationship has when estimating $f \mathrm{CO}_{2}$ or $\mathrm{pH}$ from DIC, SSS, SST, and nutrient data when $A_{t}$ was not measured, such as in 1993-1997. In particular, it is interesting to estimate how it affects trends, as done in Sect. 4.

First, we compare the computed vs. measured $A_{t}$ (Fig. B1). They present differences that tend to be correlated over a year or more, such as the lower computed values in 2001-early 2005, 2011-2012, or part of 2015. On the other hand there is no significant trend in the difference between the two during the measurement period from 2001 to 2017. Not surprisingly, the same can be said for computed $f \mathrm{CO}_{2}$ or $\mathrm{pH}$ (Fig. B1). Therefore, the conclusions on the long-term trend for $f \mathrm{CO}_{2}$ and $\mathrm{pH}$ are valid using $\mathrm{A}_{\mathrm{t}}$, either from measurements or $\mathrm{A}_{t} / S$ relation, but for short-term and process analyses measured $\mathrm{A}_{\mathrm{t}}$ should be used.

We then compare total alkalinity estimated with the SURATLANT relationship with the one using the relationship by Nondal et al. (2009) for $S>34.5$, which has a steeper slope. We also show the earlier fit of Corbière et al. (2007), which results in a larger $A_{t}$, and a fit on all the SURATLANT data, including the shelf data for $S<34$ (Fig. B2). The Nondal et al. (2009) relation for $S>34.5$ underestimates $\mathrm{A}_{\mathrm{t}}$ for low $S$ but is well within the data spread near $S=34-35$. The Corbière et al. (2007) relationship overestimates $A_{t}$ at all salinities and will not be considered later on.

We then compare $f \mathrm{CO}_{2}$ and $\mathrm{pH}$ computed with the two best estimated $\mathrm{A}_{\mathrm{t}}(S)$, which seem to cover the possible range of relationships. When applied on all the individual data, the difference $\left(f \mathrm{CO}_{2}\right.$ using the SURATLANT relationship minus $f \mathrm{CO}_{2}$ using the Nondal et al., 2009, relationship) appears as a spread for $S$ near 35, as well as for the low $S$ on the shelves (Fig. B3). For all samples for $S>34$, the mean difference is $2.4( \pm 2.00) \mu \mathrm{atm}$, i.e., lower than the uncertainty associated with $f \mathrm{CO}_{2}$ calculations. As overall changes in $S$ are not that large over the 24 years (see Appendix C) these two $\mathrm{A}_{\mathrm{t}} / S$ relations, originally based on different data sets, lead to a similar conclusion for the $f \mathrm{CO}_{2}$ trend $(+1.7-$ $\left.1.8 \mu \mathrm{atm} \mathrm{yr}^{-1}\right)$ that is close to the trend in the atmosphere. The impact on the trend in $\mathrm{pH}$ is also not significant. 

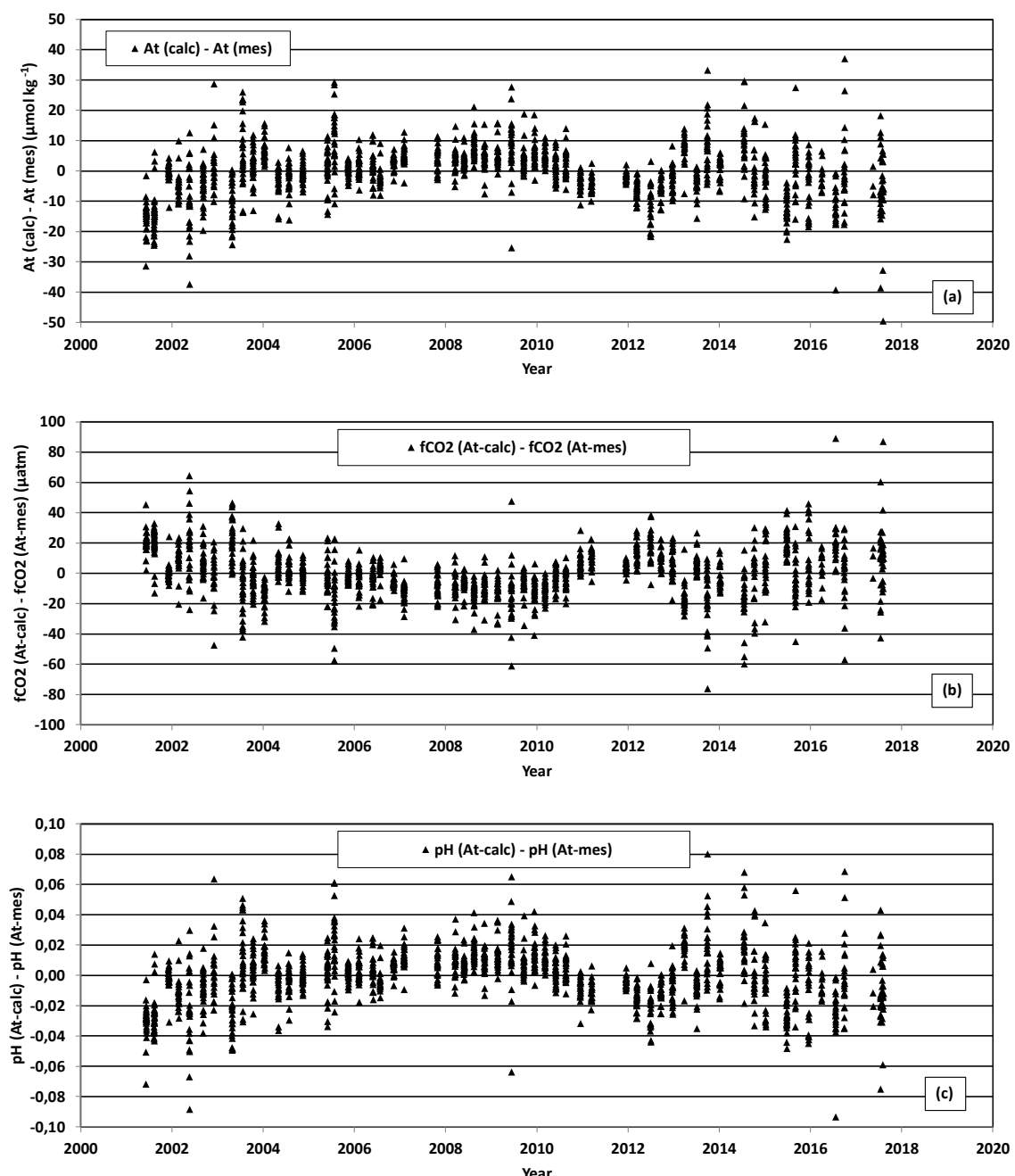

Figure B1. Comparison of the use of calculated $A_{t}$ (with SURATLANT relationship) with the use of measured $A_{t}$. (a) Difference in $A_{t}$ (calculated-measured), (b) difference in $f \mathrm{CO}_{2}$, and (c) difference in $\mathrm{pH}$.

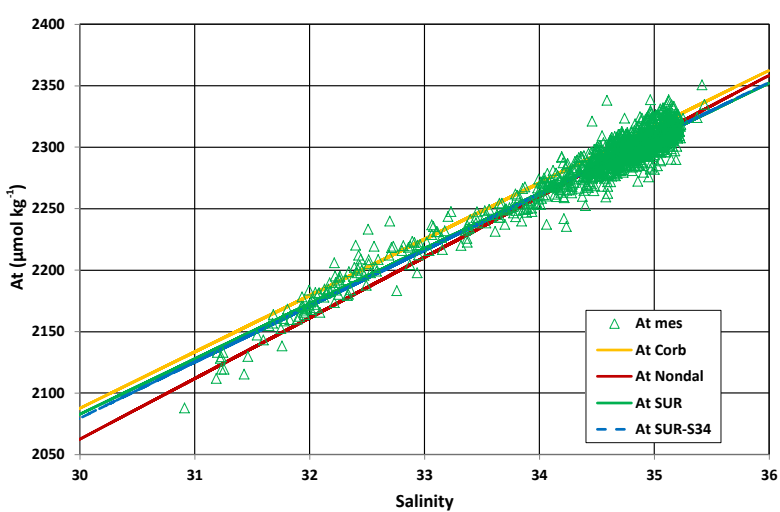

Figure B2. Scatter diagram of SURATLANT A $\mathrm{t}$ vs. $S$. Different linear fits are also presented. The blue line corresponds to the relationship adopted in this study and the red line to the Nondal et al. (2009) relationship (for $S>34.5$ ).

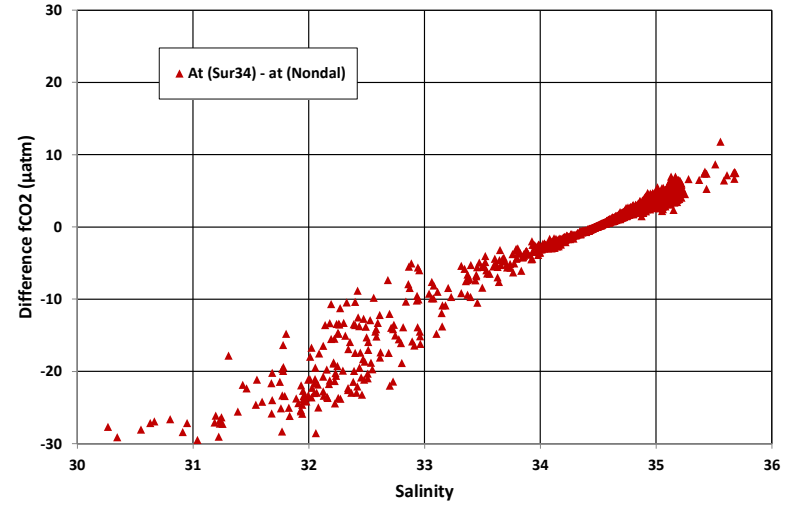

Figure B3. Difference in $f \mathrm{CO}_{2}$ estimated when using $\mathrm{A}_{\mathrm{t}}$ derived from the $S$ and SURATLANT relationship and when using $\mathrm{A}_{\mathrm{t}}$ derived from the $S$ and Nondal et al. (2009) relationship for $S>34.5$. Plot of difference $\left(f \mathrm{CO}_{2}\right)$ as a function of salinity for all SURATLANT samples. 
Appendix C: $T$ and $S$ time series in the subpolar gyre

We also estimated monthly binned temperature and salinity time series (smoothed 1-2-1 over successive months) along a standard ship route since mid-1993 (B-AX02 transect between Iceland and southern Newfoundland), which is close to where most samples were collected (Fig. 1). Most data originate from ship-mounted thermosalinographs with additional data from expendable bathythermographs, conductivitytemperature-depth probes, instrumented drifters, and floats (Argo floats or the earlier Palace floats). The data qualification, processing, and how the gridded time series are produced is reported in Reverdin et al. (2018a). To summarize the main steps, an average seasonal cycle at $1^{\circ}$ resolution is first removed from individual data and anomalies are then grouped in bins along the ship track on a monthly timescale. Gaps in the time series are filled by first linearly interpolating from neighboring spatial bins and then in time from neighboring time steps (with a further 1-2-1 running average on the monthly anomaly time series). Monthly time series along the AX02 transect start in July 1993 with few short gaps (the largest gaps are found in winter over the Newfoundland shelf and slope). These time series are useful to check whether the discrete sampling presented in this paper is able to correctly portray the interannual-decadal variability. They are also helpful in estimating the domains over which the hydrographic variability presents some coherence.

Hovmöller diagrams of $T$ and $S$ along AX02 are presented on Fig. C1. Along this transect, bins correspond usually to a $1^{\circ}$ latitude range, with two wider bins on the shelf between southern Newfoundland and the shelf break, and with two bins that correspond to the Newfoundland shelf break and slope. The $T$ and $S$ AX02 time series usually present a large correlation between successive seasons (correlation coefficient higher than 0.6), except for the two time series on the Newfoundland shelf. The $S$ variability along AX02 is very coherent in latitude from the close vicinity of Iceland to $54^{\circ} \mathrm{N}$, and after a strong increase in 1996 presents oscillations at a 4-10-year period, before a recent decrease in 20162017. The transition at $54^{\circ} \mathrm{N}$ corresponds to the North Atlantic Current frontal position further east and where the line stops paralleling the western flank of the Reykjanes Ridge. Further south over the deep ocean (until $49^{\circ} \mathrm{N}, 49^{\circ} \mathrm{W}$ ), variability in $S$ is much larger, but not similarly phased to what is observed further north, with some suggestion of a lead time of 1 to 2 years. Variability is different on the Newfoundland shelf and less coherent between successive seasons. The data sampling there is not always sufficient to be correctly portrayed in this analysis, in particular due to occasional winter or early spring ice cover, as in 1994-1995 and in 20142016. Nevertheless, it also seems to indicate negative lowfrequency anomalies until 2000 and between 2010 and 2015, as well as more positive in between, as is found further offshore.
$T$ is not well correlated to $S$, in particular at seasonal to interannual periods, but the time series are too short to identify whether correlation increases at lower frequencies. There is a large meridional coherency in the signals at least north of $50^{\circ} \mathrm{N}$. This clearly resembles the subpolar-gyre-scale AMO index or average temperature, such as presented in Robson et al. (2016). There is the clear swing from negative $T$ anomalies before 1996, and again in 2000, to maximum positive anomalies in 2004-2007 or 2010, followed by more negative anomalies (as seen in Robson et al., 2016) that have been amplified in 2014-2016.

We compared the winter $T$ and $S$ anomalies from the binned analysis (B-AX02) with the deviations from the average seasonal cycle from the discrete water samples of the SURATLANT data set. The comparison is very encouraging, as illustrated by the time series at $60^{\circ} \mathrm{N}$ (Fig. C2). Clearly the SURATLANT-reduced sampling is able to capture the largest signals in salinity (and in temperature) and thus in surface water masses. This holds also to a good extent in other seasons and less so on the Newfoundland shelf, where variability tends to be more high frequency. Notice though that there are interannual differences. For example, SURATLANT would describe (at this latitude) early 1997 as anomalously fresh, whereas B-AX02 shows near-normal salinity conditions. 
(a)

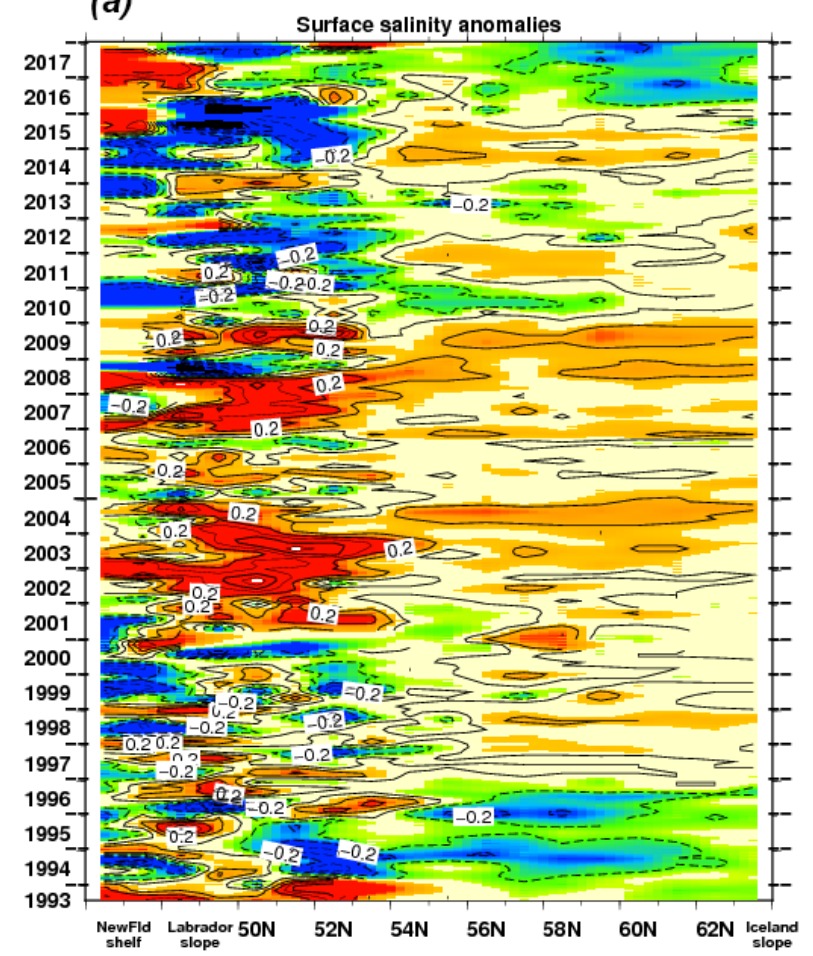

(b)

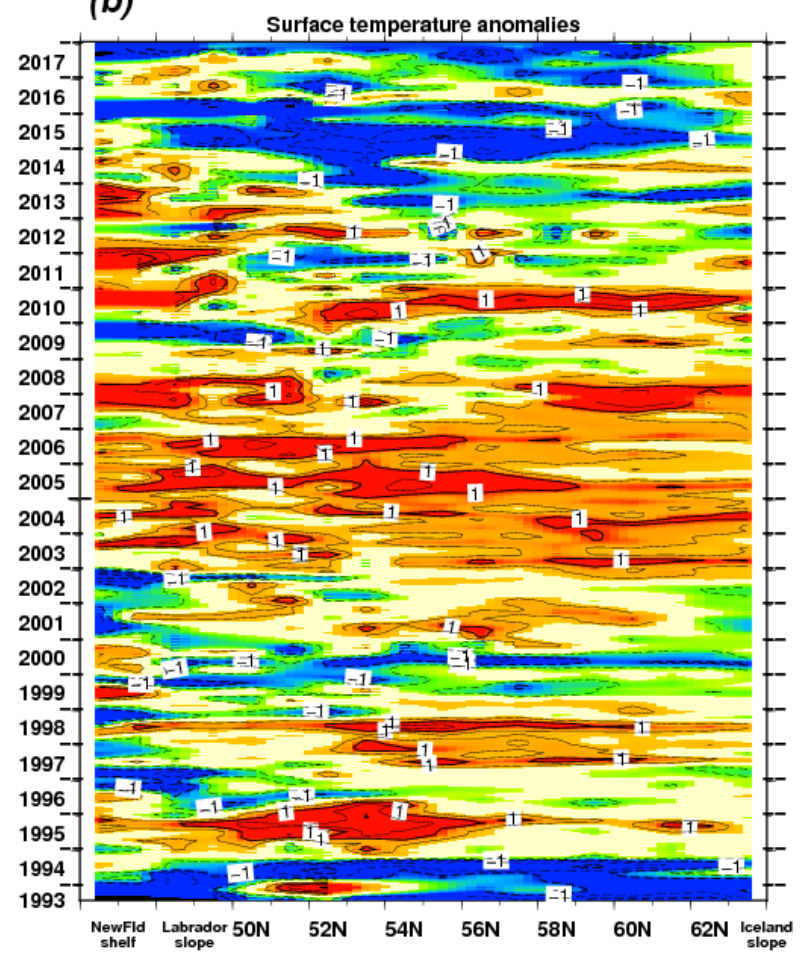

Figure C1. Hovmöller diagram along AX02 (leftmost, Newfoundland; rightmost, Iceland) of $S^{\prime}$ (a) and $T^{\prime}$ (b, $\left.{ }^{\circ} \mathrm{C}\right)$ deviations from an average seasonal cycle in July 1993-December 2017.

(a)

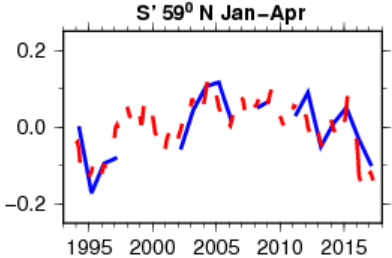

(b)

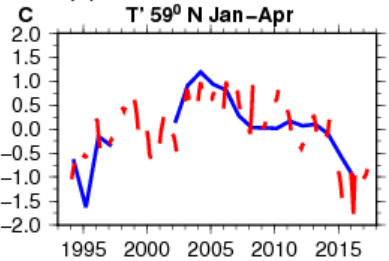

Figure C2. January-April salinity (a) and temperature (b) deviations from the seasonal cycle near $59^{\circ} \mathrm{N}$ : in red from the monthly analysis (see Fig. C1) and in blue from the discrete salinity samples (for those, the analyzed seasonal cycle is presented on Fig. 3). 
Author contributions. GR has remained the prime coordinator of the project since it was initiated in 1993 and prepared the manuscript with contributions from all co-authors. NM has been co-PI on most of the proposals since 2000 and has contributed to the collection, qualification, and validation of large parts of the data set. SO has been in charge of the nutrients since 2001 as well as intercomparison of DIC / $A_{t}$ samples and is the main Icelandic PI associated with the project. VR has been in charge of the validation of the $\delta^{13} \mathrm{C}_{\text {DIC }}$ data. TT contributed to the initiation of the project in 1993 and produced the DIC and $\mathrm{PO}_{4}$ data before 1997. $\mathrm{MB}$ has been in charge of the validation of the water stable isotope data. HV has been associated in Iceland with the initiation of the project and has supervised the analysis of salinity samples since 2000. ABC has performed the analysis of nutrient data since 2010. MD has analyzed the salinity samples since 2001. JF has performed and qualified the DIC / $A_{t}$ analyses since 2014. AN has analyzed many $\delta^{13} \mathrm{C}_{\mathrm{DIC}}$ and water stable isotope samples. DP and KS have maintained a $p \mathrm{CO}_{2}$ equilibrator on-board different vessels, whereas FB and GG have been in charge of operating the thermosalinograph and supervising the collection and validation of XBT data.

Competing interests. The authors declare that they have no conflict of interest.

Acknowledgements. The authors declare that they have no conflict of interest. Easy access on the merchant vessels run or leased by EIMSKIP has been the core of this long effort to maintain surface sampling between Iceland and Newfoundland. The nearly 100 volunteer ship riders and their enthusiasm have been key to the success of this monitoring. The project was initiated when one of the authors, GR, was at LDEO, with initial support from this institution. NOAA/AOML and NOAA/CPO Ocean Observing and Monitoring Division have contributed by maintaining the thermosalinographs and providing XBTs on the different ships that have operated between Iceland and Newfoundland. The French effort was supported by various agencies throughout the years and in particular INSU (direct support to SNO SSS and by the LEFE/CYBER grant CO2SINK and LEFE/GMMC grant GREENGROG since 2016) and IPEV. Support by National Power Company of Iceland Landsvirkjun is acknowledged. The $\delta^{13} \mathrm{C}_{\text {DIC }}$ sampling was initiated by Paul Quay (University of Washington, Seattle) in 2005-2006. SNAPO-CO2 is acknowledged for analyzing DIC / $A_{t}$ at LODYC/LOCEAN since 2001 and the isotopic platform of OSU Ecce Terra for analyzing $\delta^{13} \mathrm{C}_{\mathrm{DIC}}$ as well as water stable isotopes at LOCEAN since 2010. Collaboration between French and Icelandic investigators has been supported by PHC Jules Verne 2016 grant 36187YF. Support for Virginie Racapé was most recently provided by IFREMER and for Marion Benetti by a grant from the University of Iceland in Reykjavik. The very supportive help of Christian Brunet for the analysis of DIC / A t samples in 2001-2014 is warmly acknowledged. Support from the European Integrated Project CARBOOCEAN (511176) is also acknowledged. Some figures were plotted using Ocean Data View (ODV) (Schlitzer, 2013). Comments and suggestions by two reviewers have contributed to improve the manuscript.
Edited by: Robert Key

Reviewed by: two anonymous referees

\section{References}

Alory, G., Delcroix, T., Téchiné, P., Diverrès, D., Varillon, D., Cravatte, S., Gouriou, Y., Grelet, J., Jacquin, S., Kestenare, E., Maes, C., Morrow, R., Perrier, J., Reverdin, G., and Roubaud, F.: The French contribution to the voluntary observing ships network of sea surface salinity, Deep-Sea Res. Pt. I, 105, 1-18, https://doi.org/10.1016/j.dsr.2015.08.005, 2015.

Bakker, D. C. E., Pfeil, B., Landa, C. S., Metzl, N., O’Brien, K. M., Olsen, A., Smith, K., Cosca, C., Harasawa, S., Jones, S. D., Nakaoka, S.-I., Nojiri, Y., Schuster, U., Steinhoff, T., Sweeney, C., Takahashi, T., Tilbrook, B., Wada, C., Wanninkhof, R., Alin, S. R., Balestrini, C. F., Barbero, L., Bates, N. R., Bianchi, A. A., Bonou, F., Boutin, J., Bozec, Y., Burger, E. F., Cai, W.-J., Castle, R. D., Chen, L., Chierici, M., Currie, K., Evans, W., Featherstone, C., Feely, R. A., Fransson, A., Goyet, C., Greenwood, N., Gregor, L., Hankin, S., Hardman-Mountford, N. J., Harlay, J., Hauck, J., Hoppema, M., Humphreys, M. P., Hunt, C. W., Huss, B., Ibánhez, J. S. P., Johannessen, T., Keeling, R., Kitidis, V., Körtzinger, A., Kozyr, A., Krasakopoulou, E., Kuwata, A., Landschützer, P., Lauvset, S. K., Lefèvre, N., Lo Monaco, C., Manke, A., Mathis, J. T., Merlivat, L., Millero, F. J., Monteiro, P. M. S., Munro, D. R., Murata, A., Newberger, T., Omar, A. M., Ono, T., Paterson, K., Pearce, D., Pierrot, D., Robbins, L. L., Saito, S., Salisbury, J., Schlitzer, R., Schneider, B., Schweitzer, R., Sieger, R., Skjelvan, I., Sullivan, K. F., Sutherland, S. C., Sutton, A. J., Tadokoro, K., Telszewski, M., Tuma, M., van Heuven, S. M. A. C., Vandemark, D., Ward, B., Watson, A. J., and Xu, S.: A multidecade record of high-quality $f \mathrm{CO}_{2}$ data in version 3 of the Surface Ocean $\mathrm{CO}_{2}$ Atlas (SOCAT), Earth Syst. Sci. Data, 8, $383-$ 413, https://doi.org/10.5194/essd-8-383-2016, 2016.

Bates, N. R., Astor, Y. M., Church, M. J., Currie, K., Dore, J. E., González-Dávila, M., Lorenzoni, L., Muller-Karger, F., Olafsson, J., and Santana-Casiano, J. M.: A time-series view of changing ocean chemistry due to ocean uptake of anthropogenic $\mathrm{CO}_{2}$ and ocean acidification, Oceanography, 27, 126141, https://doi.org/10.5670/oceanog.2014.16, 2014.

Becker, M., Andersen, N., Erlenkeuser, H., Humphreys, M. P., Tanhua, T., and Körtzinger, A.: An internally consistent dataset of $\delta^{13}$ C-DIC in the North Atlantic Ocean - NAC13v1, Earth Syst. Sci. Data, 8, 559-570, https://doi.org/10.5194/essd-8-559-2016, 2016.

Benetti, M., Reverdin, G., Pierre, C., Khatiwala, S., Tournadre, B., Olafsdottir, S., and Naamar, A.: Variability of sea ice melt and meteoric water input in the surface Labrador Current off Newfoundland, J. Geophys. Res.-Oceans, 121, 2841-2855, https://doi.org/10.1002/2015JC011302, 2016.

Benetti, M., Sveinsbjörnsdottir, A. E., Olafsdottir, R., Leng, M. J., Arrowsmith, C., Debondt, K., Fripiat, F., and Aloisi, G.: Inter-comparison of salt effect correction for $\delta^{18} \mathrm{O}$ and $\delta^{2} \mathrm{H}$ measurements in seawater by CRDS and IRMS using the gas-G2O equilibration method. Mar. Chem., 194, 114-123, https://doi.org/10.1016/j.marchem.2017.05.010, 2017.

Boyer, T. P., Antonov, J. I., Baranova, O. K., Coleman, C., Garcia, H. E., Grodsky, A., Johnson, D. R., Locarnini, R. A., Mishonov, 
A. V., O'Brien, T. D., Paver, C. R., Reagan, J. R., Seidov, D., Smolyar, I. V., and Zweng, M. M.: World Ocean Database 2013, NOAA Atlas NESDIS 72, edited by: Levitus, S. and Mishonov, A., Silver Spring, MD, 209 pp., 2013.

Boyer, T. P., Levitus, S., Antonov, J., Locarini, R., Mishonov, A., Garcia, H., and Josey, S. A.: Changes in freshwater content in the North Atlantic Ocean 1955-2006, Geophys. Res. Lett., 34, L16603, https://doi.org/10.1029/2007GL030126, 2007.

Chafik, L., Häkkinen, S., England, M. H., Carton, J. A., Nigam, S., Ruiz-Barradas, A., Hannachi, A., and Miller, L.: Global linkages originating from decadal oceanic variability in the subpolar North Atlantic, Geophys. Res. Lett., 43, 10909-10919, https://doi.org/10.1002/2016GL071134, 2016GL071134, 2016.

Chipman, D. W., Marra, J., and Takahashi, T.: Primary production at $47^{\circ} \mathrm{N}$ and $20^{\circ} \mathrm{W}$ in the North Atlantic Ocean: a comparison between the $14 \mathrm{C}$ incubation method and the mixed layer carbon budget, Deep-Sea Res. Pt II, 40, 151-169, https://doi.org/10.1016/0967-0645(93)90011-B, 1993.

Corbière, A., Metzl, N., Reverdin, G., Brunet, C., and Takahashi, T.: Interannual and decadal variability of the oceanic carbon sink in the North Atlantic subpolar gyre, Tellus B, 59, 168-178, https://doi.org/10.1111/j.1600-0889.2006.00232.x, 2007.

Craig, H.: Isotopic standards for carbon and oxygen and correction factor for mass-spectrometric analysis of carbon dioxide, Geochim. Cosmochim. Acta, 12, 133-149, https://doi.org/10.1016/0016-7037(57)90024-8, 1957

Daniault, N., Mercier, H., Lherminier, P., Sarafanov, A., Falina, A., Zunino, P., Pérez, F. F., Rios, A. F., Ferron, B., Huck, T., Thierry, V., and Gladyshev, S.: The northern North Atlantic Ocean mean circulation in the early 21 st Century, Prog. Oceanogr., 146, 142158, https://doi.org/10.1016/j.pocean.2016.06.007, 2016.

De Jong, M. F. and de Steur, L.: Strong winter cooling over the Irminger Sea in winter 2014-2015, exceptional deep convection, and the emergence of anomalously low SST, Geophys. Res. Lett., 43, 7106-7113, https://doi.org/10.1002/2016GL069596, 2016.

Dlugokencky, E. J., Lang, P. M., Mund, J. W., Crotwell, A. M., Crotwell, M. J., and Thoning, K. W.: Atmospheric Carbon Dioxide Dry Air Mole Fractions from the NOAA ESRL Carbon Cycle Cooperative Global Air Sampling Network, 1968-2016, Version: 2017-07-28, available at: ftp://aftp.cmdl.noaa.gov/data/ trace_gases/co2/flask/surface/ (last access: 30 July 2018), 2017.

Edmond, J. M.: High precision determination of titration alkalinity and total carbon dioxide content of sea water by potentiometric titration, Deep-Sea Res., 17, 737-750, https://doi.org/10.1016/0011-7471(70)90038-0, 1970.

Fay, A. R. and McKinley, G. A.: Global trends in surface ocean pCO2from in situ data, Global Biogeochem. Cy., 27, 541-557, https://doi.org/10.1002/gbc.20051, 2013.

Frajka-Williams, E., Beaulieu, C., and Duchez, A.: Emerging negative Atlantic Multidecadal Oscillation index in spite of warm subtropics, Sci. Rep.-UK, 7, 11224, https://doi.org/10.1038/s41598017-11046-x, 2017.

Friedman, A. R., Reverdin, G., Khodri, M., and Gastineau, G.: A new record of Atlantic sea surface salinity from 1896 to 2013 reveals the signatures of climate variability and long-term trends, Geophys. Res. Lett., 44, 1866-1876, https://doi.org/10.1002/2017GL072582, 2017.

Friis, K., Körtzinger, A., and Wallace, D. W. R.: The salinity normalization of marine inorganic carbon chemistry data, Geophys.
Res. Lett., 30, 1085, https://doi.org/10.1029/2002GL015898, 2003.

Fröb, F., Olsen, A., Pérez, F. F., García-Ibáñez, M. I., Jeansson, E., Omar, A., and Lauvset, S. K.: Inorganic carbon and water masses in the Irminger Sea since 1991, Biogeosciences, 15, 5172, https://doi.org/10.5194/bg-15-51-2018, 2018.

Fröb, F., Olsen, A., Våge, K., Moore, K., Yashayaev, I., Jeansson, E., and Rajasakaren, B.: Irminger Sea deep convection injects oxygen and anthropogenic carbon to the ocean interior, Nat. Commun., 7, 13244, https://doi.org/10.1038/ncomms13244, 2016.

García-Ibáñez, M. I., Zunino, P., Fröb, F., Carracedo, L. I., Ríos, A. F., Mercier, H., Olsen, A., and Pérez, F. F.: Ocean acidification in the subpolar North Atlantic: rates and mechanisms controlling $\mathrm{pH}$ changes, Biogeosciences, 13, 3701-3715, https://doi.org/10.5194/bg-13-3701-2016, 2016.

Gattuso J.-P. and Hansson L. (Eds.): Ocean acidification, Oxford University Press, 326 pp., 2011

Gruber, N., Keeling, C. D., Bacastow, R. B., Guenther, P. R., Lueker, T. J., Whalen, M., Meijer, H. A. J., Mook, W. G., and Stocker, T. F.: Spatiotemporal patterns of carbon-13 in the global surface oceans and the oceanic Suess effect, Global Biogeochem. Cy., 13, 307-335, https://doi.org/10.1029/1999GB900019.1999.

Häkkinen S. and Rhines, P. B.: Decline of Subpolar North Atlantic Circulation During the 1990s, Science, 3044, 555-559, https://doi.org/10.1126/science.1094917, 2004.

Häkkinen S., Rhines, P. B., and Worthen, D. L.: Atmospheric blocking and Atlantic multidecadal ocean variability, Science, 334, 655-659, https://doi.org/10.1126/science.1205683, 2011.

Hátún, H., Sando, A. B., Drange, H., Hansen, B., and Valdimarsson, H.: Influence of the Atlantic subpolar gyre on the thermohaline circulation, Science, 309, 1841-1844, https://doi.org/10.1126/science.1114777, 2005.

Keller, K., Joos, J., Raible, C., Cocco, V., Frolicher, T., Dunne, J., Gehlen, M., Bopp, L., Orr, J., Tjiputra, J., Heinze, C., Segscheider, J., Roy, T., and Metzl, N.: Variability of the ocean carbon cycle in response to the North Atlantic Oscillation, Tellus B, 64, 18738, https://doi.org/10.3402/tellusb.v64i0.18738, 2012.

Kennedy, J. J., Rayner, N. A., Smith, R. O., Parker, D. E., and Saunby, M.: "Reassessing Biases and Other Uncertainties in Sea Surface Temperature Observations Measured in Situ since 1850: 1. Measurement and Sampling Uncertainties”, J. Geophys. Res., 116, D14103, https://doi.org/10.1029/2010JD015218, 2011.

Khatiwala, S., Tanhua, T., Mikaloff Fletcher, S., Gerber, M., Doney, S. C., Graven, H. D., Gruber, N., McKinley, G. A., Murata, A., Ríos, A. F., and Sabine, C. L.: Global ocean storage of anthropogenic carbon, Biogeosciences, 10, 2169-2191, https://doi.org/10.5194/bg-10-2169-2013, 2013.

Kroopnick, P.: Correlations between ${ }^{13} \mathrm{C}$ and $\Sigma \mathrm{CO}_{2}$ in surface waters and atmospheric $\mathrm{CO}_{2}$, Earth and Planet. Sc. Lett. 22, 397403, https://doi.org/10.1016/0012-821X(74)90150-2, 1974.

Lacour, L., Ardyna, M., Stec, K. F., Claustre, H., Prieur, L., Poteau, A., D’Alcala, M. R., Iudicone, D.: Unexpected winter phytoplankton blooms in the North Atlantic subpolar gyre, Nat. Geosci., 10, 836-839, https://doi.org/10.1038/ngeo3035, 2017.

Landschützer P., Gruber, N., and Bakker, D.: Decadal variations and trends of the global ocean carbon sink, Global Biogeochem. Cy., 30, 1396-1417, https://doi.org/10.1002/2015GB005359, 2016. 
Lauvset, S. K. and Gruber, N.: Long-term trends in surface ocean $\mathrm{pH}$ in the North Atlantic, Mar. Chem., 162, 71-76, https://doi.org/10.1016/j.marchem.2014.03.009, 2014.

Lauvset, S. K., Gruber, N., Landschützer, P., Olsen, A., and Tjiputra, J.: Trends and drivers in global surface ocean $\mathrm{pH}$ over the past 3 decades, Biogeosciences, 12, 1285-1298, https://doi.org/10.5194/bg-12-1285-2015, 2015.

Le Quéré, C., Andrew, R. M., Friedlingstein, P., Sitch, S., Pongratz, J., Manning, A. C., Korsbakken, J. I., Peters, G. P., Canadell, J. G., Jackson, R. B., Boden, T. A., Tans, P. P., Andrews, O. D., Arora, V. K., Bakker, D. C. E., Barbero, L., Becker, M., Betts, R. A., Bopp, L., Chevallier, F., Chini, L. P., Ciais, P., Cosca, C. E., Cross, J., Currie, K., Gasser, T., Harris, I., Hauck, J., Haverd, V., Houghton, R. A., Hunt, C. W., Hurtt, G., Ilyina, T., Jain, A. K., Kato, E., Kautz, M., Keeling, R. F., Klein Goldewijk, K., Körtzinger, A., Landschützer, P., Lefèvre, N., Lenton, A., Lienert, S., Lima, I., Lombardozzi, D., Metzl, N., Millero, F., Monteiro, P. M. S., Munro, D. R., Nabel, J. E. M. S., Nakaoka, S.-I., Nojiri, Y., Padin, X. A., Peregon, A., Pfeil, B., Pierrot, D., Poulter, B., Rehder, G., Reimer, J., Rödenbeck, C., Schwinger, J., Séférian, R., Skjelvan, I., Stocker, B. D., Tian, H., Tilbrook, B., Tubiello, F. N., van der Laan-Luijkx, I. T., van der Werf, G. R., van Heuven, S., Viovy, N., Vuichard, N., Walker, A. P., Watson, A. J., Wiltshire, A. J., Zaehle, S., and Zhu, D.: Global Carbon Budget 2017, Earth Syst. Sci. Data, 10, 405-448, https://doi.org/10.5194/essd-10-405-2018, 2018.

Lewis, E. and Wallace, D. W. R.: Program Developed for $\mathrm{CO}_{2}$ System Calculations, ORNL/CDIAC-105, Carbon Dioxide Information Analysis Center, Oak Ridge National Laboratory, US Department of Energy, Oak Ridge, Tennessee, 1998.

Lueker, T. J., Dickson, A. G., and Keeling, C. D.: Ocean $p \mathrm{CO}_{2}$ calculated from dissolved inorganic carbon, alkalinity, and equations for $\mathrm{K} 1$ and $\mathrm{K} 2$ : validation based on laboratory measurements of $\mathrm{CO}_{2}$ in gas and seawater at equilibrium, Mar. Chem., 70, 105-119, https://doi.org/10.1016/S0304-4203(00)00022-0, 2000.

McKinley, G. A., Fay, A. R. Takahashi, T., and Metzl, N.: Convergence of atmospheric and North Atlantic carbon dioxide trends on multidecadal timescales, Nature Geosci., 4, 606-610, https://doi.org/10.1038/NGEO1193, 2011.

McNeil, B., Matear, R., and Tilbrook, B.: Does carbon 13 track anthropogenic $\mathrm{CO}_{2}$ in Southern ocean, Global Biogeochem. Cy., 15, 597-613, https://doi.org/10.1029/2000GB001352. 2001

McTigue, N. D., Gardner, W. S., Hunton, K. H., and Hardison, A. K.: Biotic and abiotic controls on co-occurring nitrogen cycling processes in shallow Arctic shelf sediments, Nat. Commun., 7, 13145 https://doi.org/10.1038/ncomms13145, 2016.

Mercier, H., Lherminier, P., Sarafanov, A., Gaillard, F., Daniault, N., Desbruyères, D., Falina, A., Ferron, B., Gourcuff, C., Huck, T., and Thierry, V.: Variability of the meridional overturning circulation at theGreenland-Portugal OVIDE section from 1993 to 2010, Prog. Oceanogr., 132, 250-261, https://doi.org/10.1016/j.pocean.2013.11.001, 2015.

Metzl, N., Corbière, A., Reverdin, G., Lenton, A., Takahashi, T., Olsen, A., Johannessen, T., Pierrot, D., Wanninkhof, R., Ólafsdóttir, S. R., Olafsson, J., and Ramonet, M.: Recent acceleration of the sea surface $f \mathrm{CO}_{2}$ growth rate in the North Atlantic subpolar gyre (1993-2008) revealed by winter observations, Global Biogeochem. Cy., 24, GB4004, https://doi.org/10.1029/2009GB003658, 2010.

Millero, F. J., Lee, K., and Roche, M.: Distribution of alkalinity in the surface waters of the major oceans, Mar. Chem., 60, 111-130, https://doi.org/10.1016/S0304-4203(97)00084-4, 1998.

Nondal, G., Bellerby, R. G. J., Olsen, A., Johannessen, T., and Olafsson, J.: Optimal evaluation of the surface ocean $\mathrm{CO}_{2}$ system in the northern North Atlantic using data from voluntary observing ships, Limnol. Oceanogr., 7, 109-118, https://doi.org/10.4319/lom.2009.7.109, 2009.

Olafsson, J., Olafsdottir, S. R., Benoit-Cattin, A., Danielsen, M., Arnarson, T. S., and Takahashi, T.: Rate of Iceland Sea acidification from time series measurements, Biogeosciences, 6, 26612668, https://doi.org/10.5194/bg-6-2661-2009, 2009.

Olafsson, J., Olafsdottir, S. R., Benoit-Cattin, A., and Takahashi, T.: The Irminger Sea and the Iceland Sea time series measurements of sea water carbon and nutrient chemistry 1983-2008, Earth Syst. Sci. Data, 2, 99-104, https://doi.org/10.5194/essd-299-2010, 2010.

Olsen, A., Key, R. M., van Heuven, S., Lauvset, S. K., Velo, A., Lin, X., Schirnick, C., Kozyr, A., Tanhua, T., Hoppema, M., Jutterström, S., Steinfeldt, R., Jeansson, E., Ishii, M., Pérez, F. F., and Suzuki, T.: The Global Ocean Data Analysis Project version 2 (GLODAPv2) - an internally consistent data product for the world ocean, Earth Syst. Sci. Data, 8, 297-323, https://doi.org/10.5194/essd-8-297-2016, 2016.

Olsen, A., Omar, A. M., Bellerby, R. G. J., Johannessen, T., Ninnemann,U., Brown, K. R., Olsson, K. A., Olafsson, J., Nondal, G.,Kivimäe, C., Kringstad, S., Neill, C., and Ólafsdóttir, S. R.: Magnitude and origin of the anthropogenic $\mathrm{CO}_{2}$ increase and Suess effect in the Nordic seas since 1981, Global Biogeochem. Cy., 20, 1-12, https://doi.org/10.1029/2005GB002669, 2006.

Organelli, E., Barbieux, M., Claustre, H., Schmechtig, C., Poteau, A., Bricaud, A., Boss, E., Briggs, N., Dall'Olmo, G., D’Ortenzio, F., Leymarie, E., Mangin, A., Obolensky, G., Penkerc'h, C., Prieur, L., Roesler, C., Serra, R., Uitz, J., and Xing, X.: Two databases derived from BGC-Argo float measurements for marine biogeochemical and bio-optical applications, Earth Syst. Sci. Data, 9, 861-880, https://doi.org/10.5194/essd-9-861-2017, 2017.

Pierrot, D., Lewis, D. E., and Wallace, D. W. R.: MS Excel Program Developed for $\mathrm{CO}_{2}$ System Calculations, ORNL/CDIAC-105a, Carbon Dioxide Information Analysis Center, Oak Ridge National Laboratory, U.S. Department of Energy, Oak Ridge, Tennessee, https://doi.org/10.3334/CDIAC/otg.CO2SYS_XLS_CDIAC105a, 2006.

Pierrot, D., Neill, C., Sullivan, K., Castle, R., Wanninkhof, R., Lüger, H., Johannessen, T., Olsen, A., Feely, R. A., and Cosca, C. E.: Recommendations for autonomous underway $p \mathrm{CO}_{2}$ measuring systems and data-reduction routines, Deep-Sea Res. Pt. II, 56, 512-522, https://doi.org/10.1016/j.dsr2.2008.12.005, 2009.

Piron, A., Thierry, V., Mercier, H., and Caniaux, G.: Gyre-scale deep convection in the subpolar North Atlantic Ocean during winter 2014-2015, Geophys. Res. Lett., 44, 1439-1447, https://doi.org/10.1002/2016GL071895, 2017.

Quay, P. and Stutsman, J.: Surface layer carbon budget for the subtropical N. Pacific: $\delta^{13} \mathrm{C}$ constraints at station ALOHA, Deep- 
Sea Res. Pt. I, 50, 1045-1061, https://doi.org/10.1016/S09670637(03)00116-X.,2003.

Racapé, V., Pierre, C., Metzl, N., Lo Monaco, C., Reverdin, G., Olsen, A., Morin, P., Vasquez-Rodriguez, M., Rios, A., and Perez, F.: Anthropogenic carbon changes in the Irminger Basin (1981-2006): coupling $\delta^{13} \mathrm{C}_{\text {DIC }}$ and DIC observations, J. Mar. Sys., 126, 24-32, https://doi.org/10.1016/j.jmarsys.2012.12.005, 2013.

Racapé, V., Metzl, N., Pierre, C., Reverdin, G., Quay, P. D., and Olafsdottir, S. R.: The seasonal cycle of $\delta^{3} \mathrm{C}_{\text {DIC }}$ in the North Atlantic subpolar gyre, Biogeosciences, 11, 1683-1692, https://doi.org/10.5194/bg-11-1683-2014, 2014.

Rahmstorf, S., Box, J. E., Feulner, G., Mann, M. E., Robinson, A., Rutherford, S., and Schaffernicht, E. J.: Exceptional twentieth-century slowdown in Atlantic Ocean overturning circulation, Nat. Clim. Change, 5, 475-480, https://doi.org/10.1038/nclimate2554, 2015.

Reverdin, G.: North Atlantic subpolar gyre surface variability (1895-2009), J. Climate, 17, 4571-4584, https://doi.org/10.1175/2010JCLI3493.1, 2010.

Reverdin, G., Metzl, N., and Corbière, A.: Carbon dioxide measurement results in the north Atlantic subploar gyre during SURATLANT cruise AGSK20040110, Laboratoire d'Océanographie et du Climat: Expérimentation et Approches Numériques, Université Pierre-et-Marie-Curie, France, Unpublished dataset no.603247, https://doi.org/10.1594/PANGAEA.603247, 2007.

Reverdin, G., Ólafsdóttir, S. R., and Metzl, N.: Hydrochemistry measured on water bottle samples in the North Atlantic subpolar gyre during SURATLANT cruise 64RJ20130704, PANGAEA, https://doi.org/10.1594/PANGAEA.844132, 2015.

Reverdin, G., Valdimarsson, H., Alory, G., Diverres, D., Bringas, F., Goni, G., Heilmann, L., Chafik, L., Szekely, T., and Friedman, A. R.: North Atlantic subpolar gyre along predetermined ship tracks since 1993: a monthly data set of surface temperature, salinity, and density, Earth Syst. Sci. Data, 10, 1403-1415, https://doi.org/10.5194/essd-10-1403-2018, 2018a.

Reverdin, G., Metzl, N., Olafsdottir, S., Racapé, V., Takahashi, T., Benetti, M., Valdimarsson, H., Quay, P. D., Benoit-Cattin, A., Danielsen, M., Fin, J., Naamar, A., Pierrot, D., Sullivan, K., Bringas, F., and Goni, G.: SURATLANT: a 1993-2017 surface dataset in the central part of the North Atlantic subpolar gyre, SEANOE, https://doi.org/10.17882/54517 (last access: $20 \mathrm{Au}-$ gust 2018b).

Robson, J., Ortega, P., and Sutton, R.: A reversal of climate trends in the North Atlantic since 2005, Nat. Geosci., 9, 513-517, https://doi.org/10.1038/ngeo2727, 2016.

Rödenbeck, C., Bakker, D. C. E., Gruber, N., Iida, Y., Jacobson, A. R., Jones, S., Landschützer, P., Metzl, N., Nakaoka, S., Olsen, A., Park, G.-H., Peylin, P., Rodgers, K. B., Sasse, T. P., Schuster, U., Shutler, J. D., Valsala, V., Wanninkhof, R., and Zeng, J.: Data-based estimates of the ocean carbon sink variability - first results of the Surface Ocean $p \mathrm{CO}_{2}$ Mapping intercomparison (SOCOM), Biogeosciences, 12, 72517278, https://doi.org/10.5194/bg-12-7251-2015, 2015.

Rödenbeck, C., Bakker, D. C. E., Metzl, N., Olsen, A., Sabine, C., Cassar, N., Reum, F., Keeling, R. F., and Heimann, M.: Interannual sea-air $\mathrm{CO} 2$ flux variability from an observationdriven ocean mixed-layer scheme, Biogeosciences, 11, 4599_ 4613, https://doi.org/10.5194/bg-11-4599-2014, 2014.
Rossby, T., Reverdin, G., Chafik, L., and Søiland, H.: A direct estimate of poleward volume, heat, and freshwater fluxes at $59.5^{\circ} \mathrm{N}$ between Greenland and Scotland, J. Geophys. Res.-Oceans, 122, 5870-5887, https://doi.org/10.1002/2017JC012835., 2017

Sarthou, G. and Lherminier, P.: GEOVIDE cruise, RV Pourquoi pas?, https://doi.org/10.17600/14000200, 2014.

Schlitzer, R.: Ocean Data View, available at: http:/odv.awi.de (last access: 17 May 2014), 2013.

Schmidt, G. A., Bigg, G. R., and Rohling, E. J.: Global Seawater Oxygen-18 Database, NASA Goddard Inst of Space Sci., New York, available at: http://data.giss.nasa.gov/o18data/ (last access: 30 July 2018), 1999.

Schuster, U., Watson, A. J., Bates, N., Corbière, A., Gonzalez-Davila, M., Metzl, N., Pierrot, D., and SantanaCasiano, M.: Trends in North Atlantic sea surface $p \mathrm{CO}_{2}$ from 1990 to 2006, Deep-Sea Res. Pt. II, 56, 620-629, https://doi.org/10.1016/j.dsr2.2008.12.011, 2009

Schuster, U., McKinley, G. A., Bates, N., Chevallier, F., Doney, S. C., Fay, A. R., González-Dávila, M., Gruber, N., Jones, S., Krijnen, J., Landschützer, P., Lefèvre, N., Manizza, M., Mathis, J., Metzl, N., Olsen, A., Rios, A. F., Rödenbeck, C., Santana-Casiano, J. M., Takahashi, T., Wanninkhof, R., and Watson, A. J.: An assessment of the Atlantic and Arctic sea-air $\mathrm{CO}_{2}$ fluxes, 1990-2009, Biogeosciences, 10, 607-627, https://doi.org/10.5194/bg-10-607-2013, 2013.

Signorini, S. R., Häkkinen, S., Gudmundsson, K., Olsen, A., Omar, A. M., Olafsson, J., Reverdin, G., Henson, S. A., McClain, C. R., and Worthen, D. L.: The role of phytoplankton dynamics in the seasonal and interannual variability of carbon in the subpolar North Atlantic - a modeling study, Geosci. Model Dev., 5, 683 707, https://doi.org/10.5194/gmd-5-683-2012, 2012.

Skrzypek, G. and Ford, D.: Stable Isotope analysis of saline water samples on a cavity 546 ring-down spectroscopy instrument, Environ. Sci. Technol., 48, 2827-2834, https://doi.org/10.1021/es4049412, 2014.

Sonnerup, R. E. and Quay, P. D.: ${ }^{13} \mathrm{C}$ constraints on ocean carbon cycle models, Global Biogeochem. Cy., 26, GB2014, https://doi.org/10.1029/2010GB003980, 2012.

Tagliabue, A. and Bopp, L.: Towards understanding global variability in ocean carbon-13, Global Biogeochem. Cy., 22, GB1025, https://doi.org/10.1029/2007GB003037, 2008.

Takahashi, T., Sutherland, S. C., Sweeney, C., Poisson, A., Metzl, N., Tilbrook, B., Bates, N., Wanninkhof, R., Feely, R. A., Sabine, C., Olafsson, J., and Nojiri, Y.: Global Sea-Air $\mathrm{CO}_{2}$ Flux Based on Climatological Surface Ocean $p \mathrm{CO}_{2}$, and Seasonal Biological and Temperature Effect, Deep-Sea Res. Pt. II, 49, 1601-1622, https://doi.org/10.1016/S0967-0645(02)00003-6, 2002.

Takahashi, T., Sutherland, S. C., Wanninkhof, R., Sweeney, C., Feely, R. A., Chipman, D. W., Hales, B., Friederich, G., Chavez, F., Sabine, C., Watson, A. J., Bakker, D. C., Schuster, U., Metzl, N., Yoshikawa-Inoue, H., Ishii, M., Midorikawa, T., Nojiri, Y., Körtzinger, A., Steinhoff, T., Hoppema, M., Olafsson, J., Arnarson, T. S., Tilbrook, B., Johannessen, T., Olsen, A., Bellerby, R., Wong, C., Delille, B., Bates, N., and de Baar, H. J.: Climatological mean and decadal change in surface ocean $p \mathrm{CO}_{2}$, and net sea air $\mathrm{CO}_{2}$ flux over the global oceans , Deep-Sea Res. Pt. II, 56, 554-577 https://doi.org/10.1016/j.dsr2.2008.12.009, 2009.

Takahashi, T., Sutherland, S. C., Chipman, D. W., Goddard, J. G., Cheng Ho, Newberger, T., Sweeney, C., and Munro, D. R.: Cli- 
matological Distributions of $\mathrm{pH}, p \mathrm{CO}_{2}$, Total $\mathrm{CO}_{2}$, Alkalinity, and $\mathrm{CaCO}_{3}$ Saturation in the Global Surface Ocean, and Temporal Changes at Selected Locations, Mar. Chem., 164, 95-125, https://doi.org/10.1016/j.jmarchem.2014.06.004, 2014.

Thierry, V.: RREX 2017 cruise, RV Atalante, https://doi.org/10.17600/17001400, 2017.

Thomas, H., Prowe, A. E. F., Lima, I. D., Doney, S. C., Wannikhof, R., Greatbatch, R. J., Schuster, U., and Corbière, A.: Changes in the North Atlantic Oscillation influence on $\mathrm{CO}_{2}$ uptake in the North Atlantic over the past two decades, Global Biogeochem. Cy., 22, GB4027, https://doi.org/10.1029/2007GB003167, 2008.

Vangriesheim, A., Pierre, C., Aminot A., Metzl, N., Baurand, F., and Caprais, J.-C.: The influence of Congo River discharges in the surface and deep layers of the Gulf of Guinea, Deep-Sea Res. Pt. II, 56, 2183-2196, https://doi.org/10.1016/j.dsr2.2009.04.002, 2009.

Wanninkhof, R. and Trinanes, J.: The impact of changing wind speeds on gas transfer and its effect on global airsea $\mathrm{CO}_{2}$ fluxes, Global Biogeochem. Cy., 31, 961-974, https://doi.org/10.1002/2016GB005592, 2017.

Watson, A.J., Schuster, U., Bakker, D. C. E., Bates, N., Corbiere, 1., Gonzalez-Davila, M., Freidrich, T., Hauck, J., Heinze, C., Johannessen, T., Koertzinger, A., Metzl, N., Olafsson, J., Olsen, A., Oschlies, A., Padin, X., Pfeil, B., Rios, A., Santana-Casiano, M., Steinhoff, T., Telszewski, M., Wallace, D. W. R., and Wanninkhof, R.: Tracking the variable North Atlantic sink for atmospheric $\mathrm{CO}_{2}$, Science, 326, 1391, https://doi.org/10.1126/science.1177394, 2009
Weiss, R. and Price, B.: Nitrous oxide solubility in water and seawater, Mar. Chem., 8, 347-359, https://doi.org/10.1016/03044203(80)90024-9, 1980.

White, J. W. C., Vaughn, B. H., and Michel, S. E.: University of Colorado, Institute of Arctic and Alpine Research (INSTAAR), Stable Isotopic Composition of Atmospheric Carbon Dioxide $\left({ }^{13} \mathrm{C}\right.$ and $\left.{ }^{18} \mathrm{O}\right)$ from the NOAA ESRL Carbon Cycle Cooperative Global Air Sampling Network, 1990-2014, Version: 2015-10-26, available at: ftp://aftp.cmdl.noaa.gov/data/ trace_gases/co2c13/flask/ (last access: 30 July 2018), 2015.

Yashayaev, I. and Loder, J. W.: Recurrent replenishment of Labrador Sea water and associated decadalscale variability, J. Geophys. Res., 8095-8114, https://doi.org/10.1002/2016JC012046, 2016.

Zunino, P., Garcia-Ibañez, M. I., Lherminier, P., Mercier, H., Rios, A. F., and Pérez, F. F.: Variability of the transport of anthropogenic $\mathrm{CO}_{2}$ at the Greenland-Portugal OVIDE section: controlling mechanisms, Biogeosciences, 11, 2375-2389, https://doi.org/10.5194/bg-11-2375-2014, 2014. 